Running Head: FORD

\title{
Ford and the New Auto Industry
}

\author{
A Case Study by \\ Jose Daniel Arroyo \\ State University of New York School for Graduate Studies \\ 27-Apr-18
}

Author note:

This is the final paper the Global Strategic Management and Leadership graduate level course presented by Drs. Alan Belasen \& Betul Lus.

This case study is submitted to fulfill the requirements for the degree of Master of Business Administration in Global Leadership

All correspondence concerning this article should be addressed to Jose_arroyo144@esc.edu 


\section{Executive Summary}

The iconic Ford Motor Company is considered one of the pillars of the automotive industry. Its first vehicle, the Model T, introduced the concept of mass production and automobile affordability to the masses.

\section{Current Situation}

Today, the market is full of domestic and foreign competitors, yet, Ford has struggled to remain competitive, even though it promotes itself as America's best-selling brand. Its stock was recently downgraded, and recently, it announced its intentions to only sell sports utility vehicles, trucks, Mustangs and Focus, in other words, it will stop selling most of its passenger cars. Conversely, Toyota continues to lead the market in passenger car sales, while newcomer Tesla struggles to deliver on its backlog of 500,000 electric vehicle orders.

\section{Strategic Audit}

Ford has a strong brand equity, has automated production facilities and a large franchised dealer network across the globe. Yet, it is rapidly losing passenger car market share, its profits are eroding, and its new vision is confusing. Furthermore, the company is facing a significant threat from well capitalized new competitors entering from the tech industry.

\section{Country Analysis}

The company, on the other hand, has enjoyed significant success in mainland China, where the demand for American automobiles continuous to be strong. Yet, the company needs to assume a cost leadership position and attempt to use this strategy to increase market share.

\section{World Strategy}

The adequate approach for the company appears to be a combination of market penetration in the domestic front, market expansion in Asia and other parts of the globe, and a product development approach that ushers cost reductions.

\section{Human Resources}

As the company works on a workforce reduction plan, it is important to keep diversity in the front-runner position. It is also necessary that human resources play a key role in the selection, transition, and retraining of the individuals that stay and the ones that are separated from the company. Moreover, adopting of a continuous learning program will go long ways in the company's search for increase efficiencies.

Key Words: Ford, PESTEL, VRIO, Strategy 


\section{TABLE OF CONTENTS}

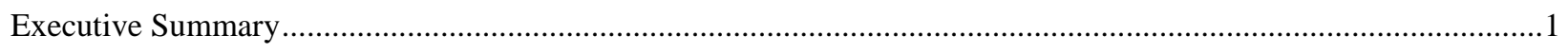

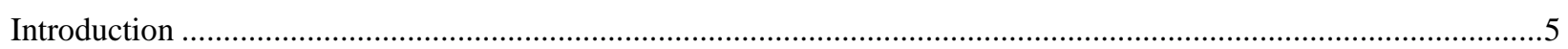

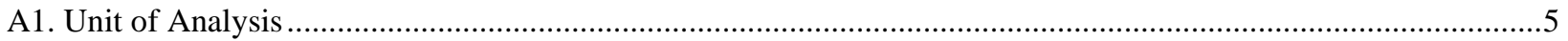

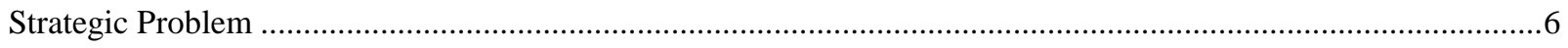

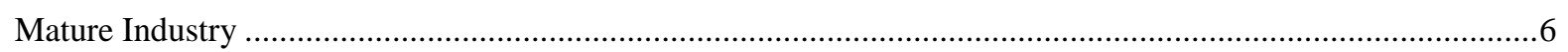

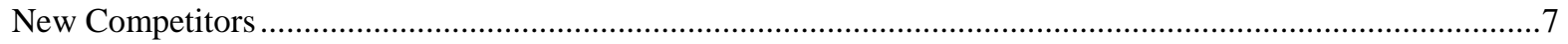

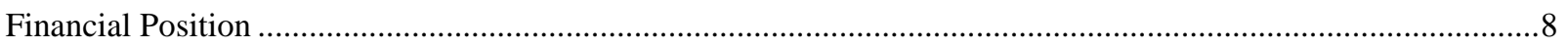

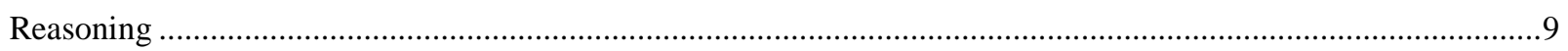

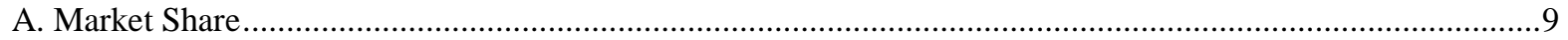

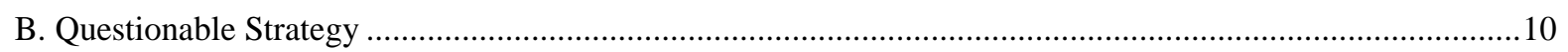

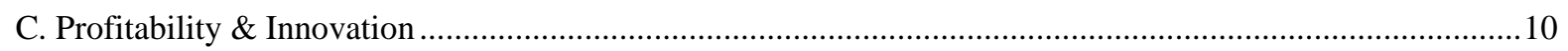

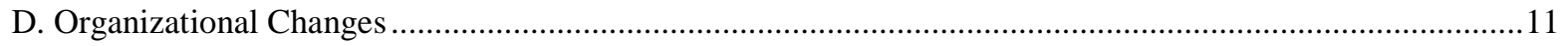

Potential Solutions

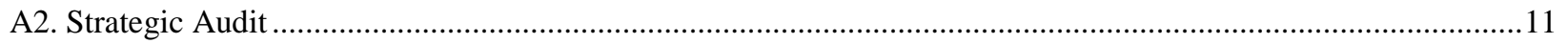

Strategic Problem - Current Situation ..........................................................................................................

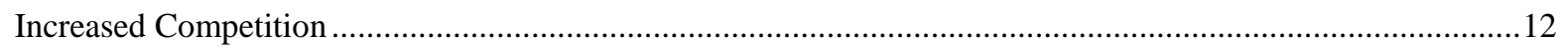

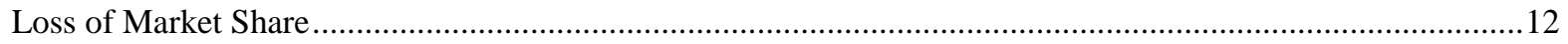

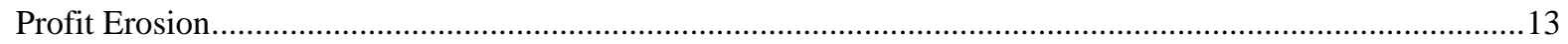

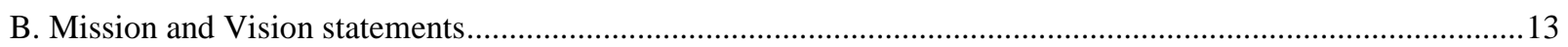

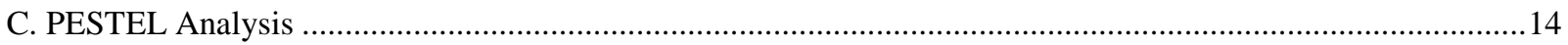

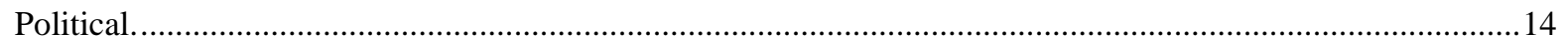

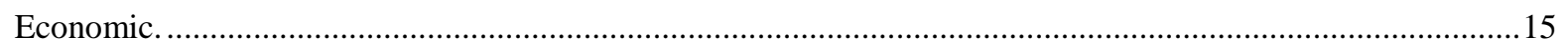

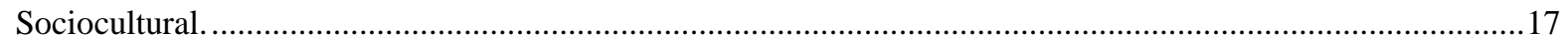

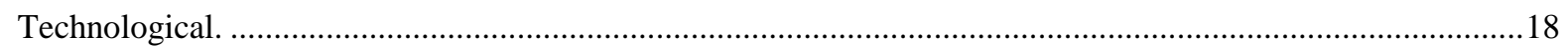

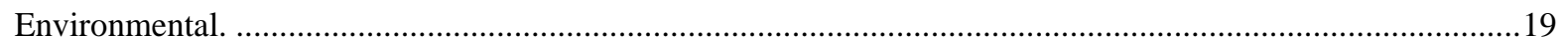

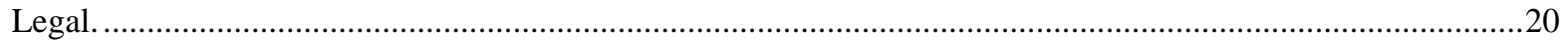

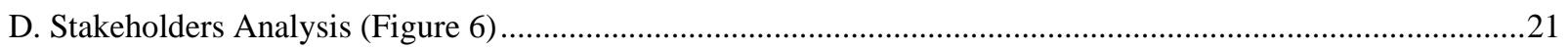

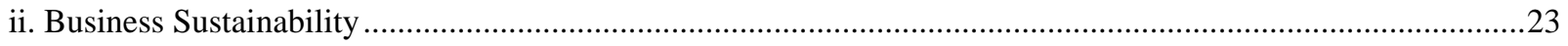

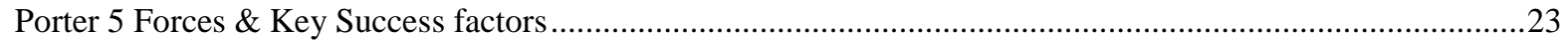

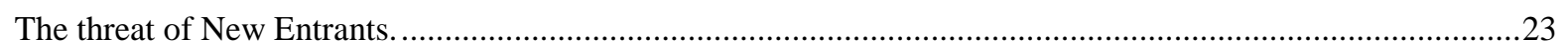

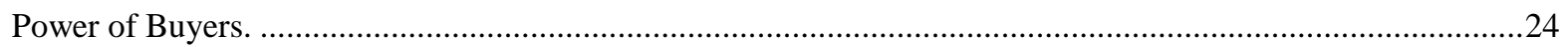

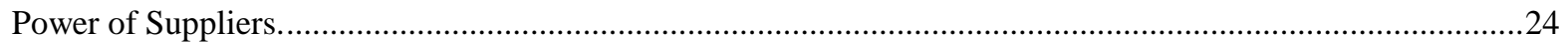

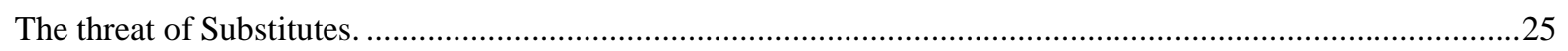

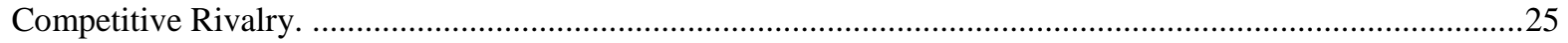

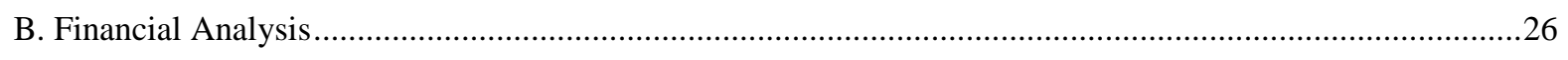

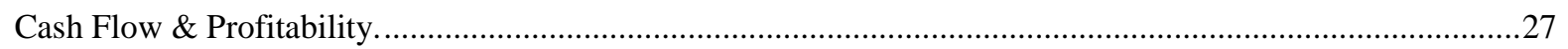

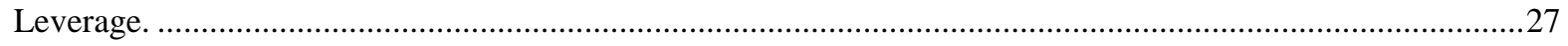

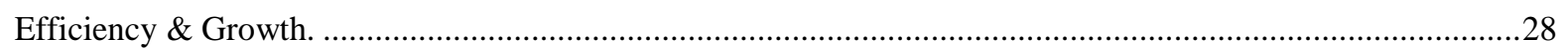




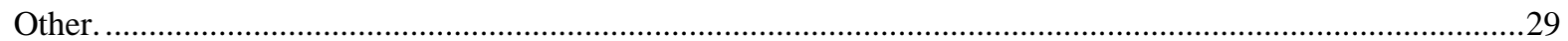

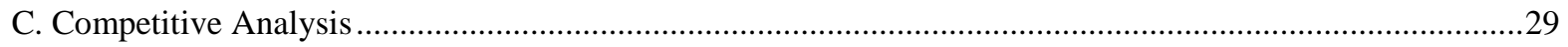

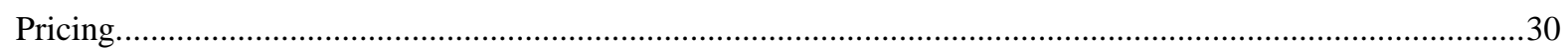

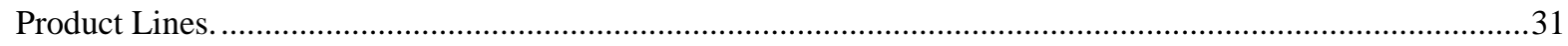

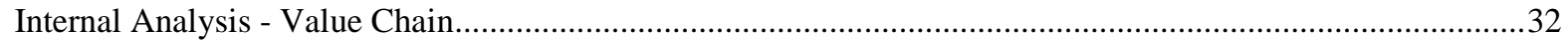

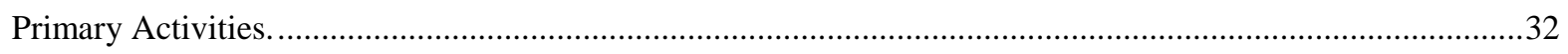

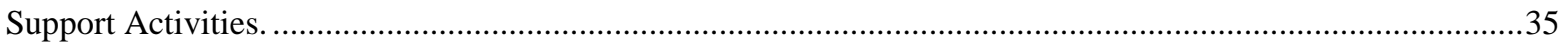

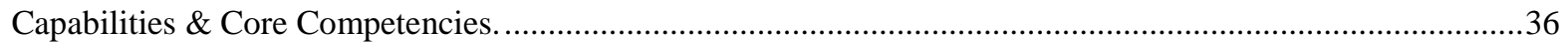

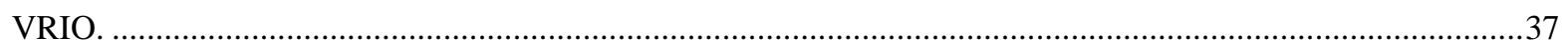

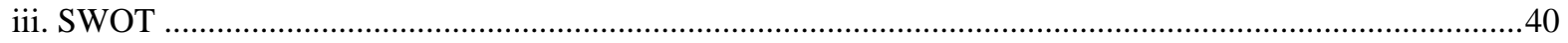

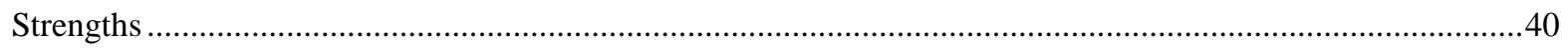

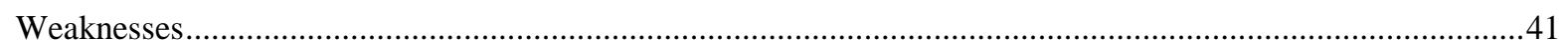

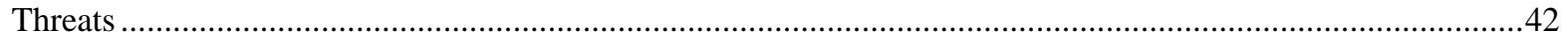

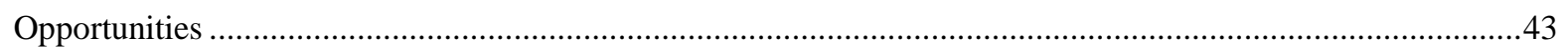

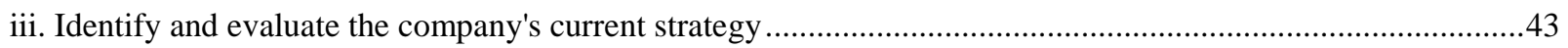

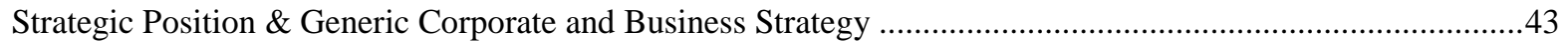

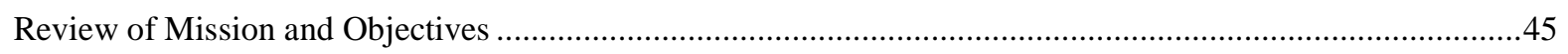

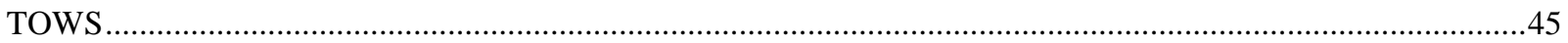

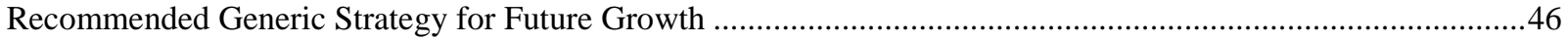

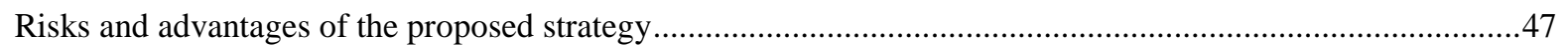

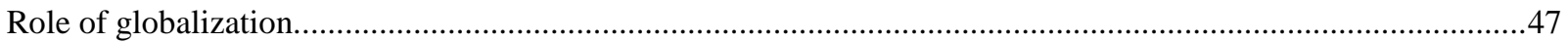

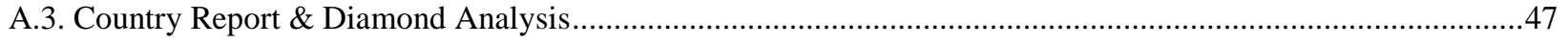

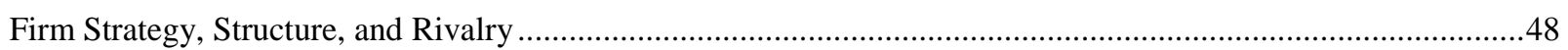

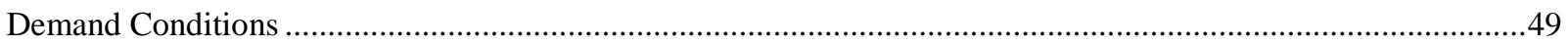

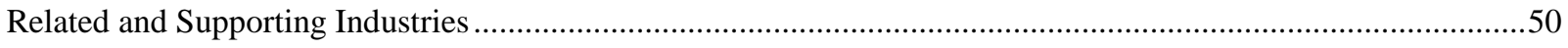

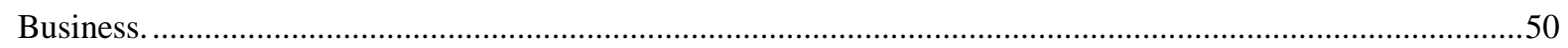

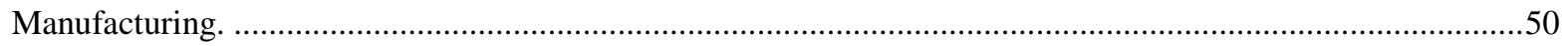

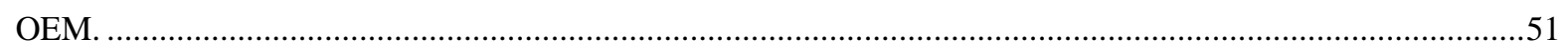

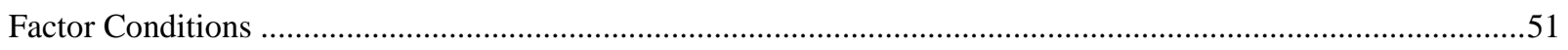

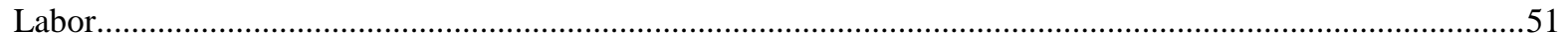

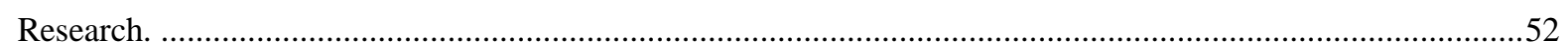

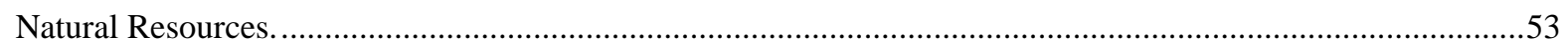

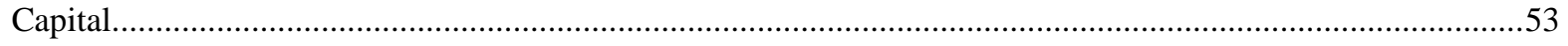

Culture

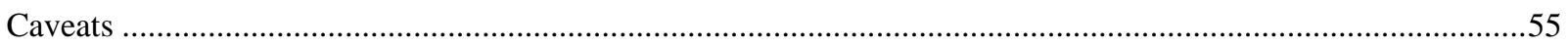

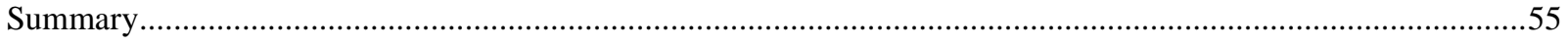

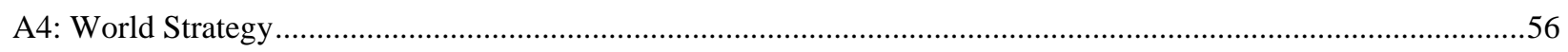

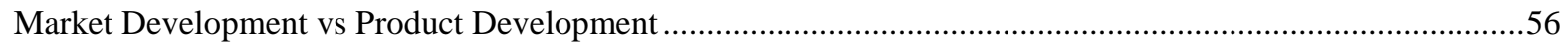

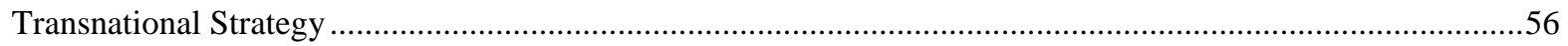




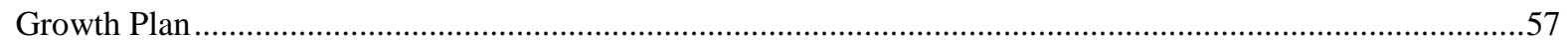

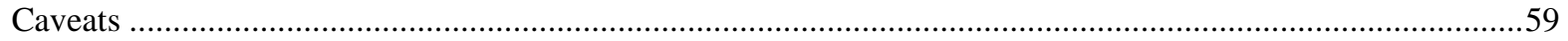

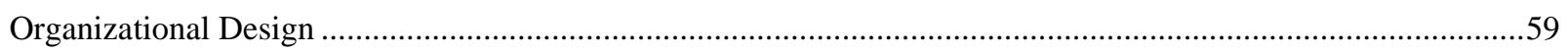

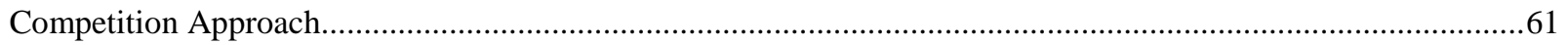

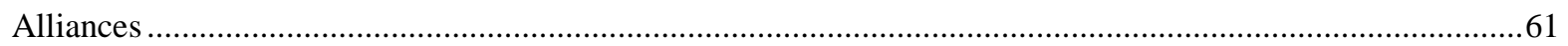

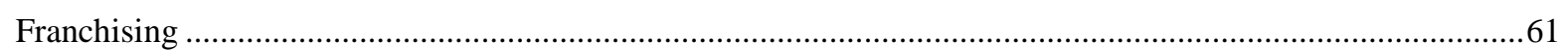

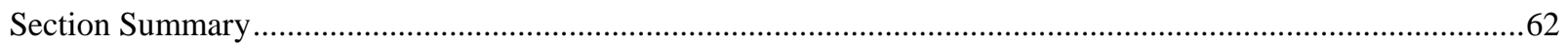

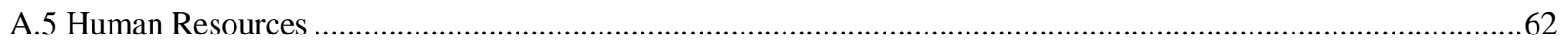

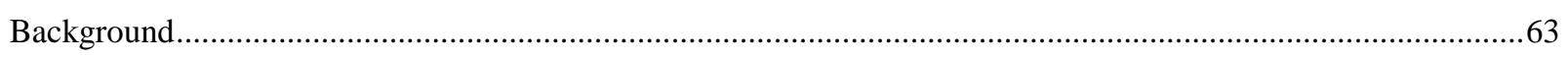

HR Functions

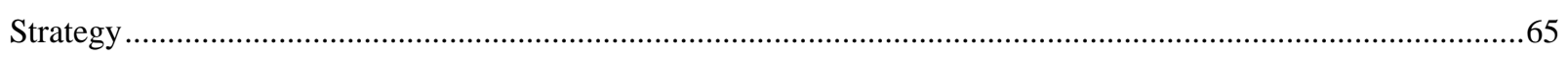

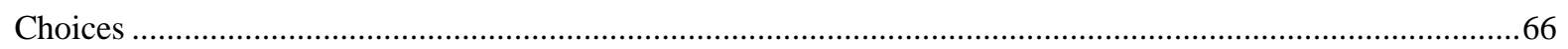

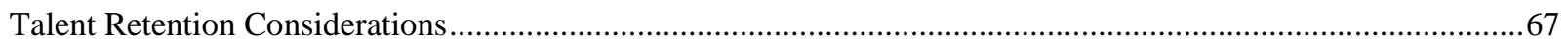

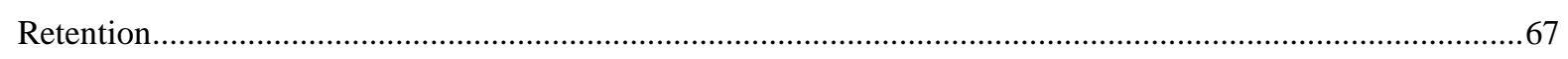

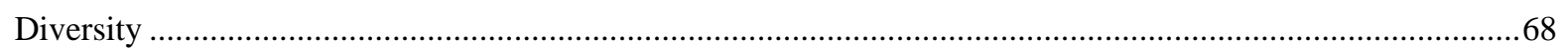

Geocentric Approach ....................................................................................................................69

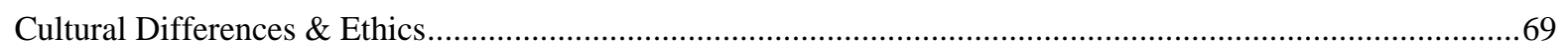

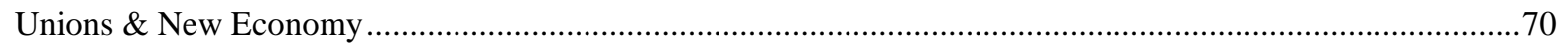

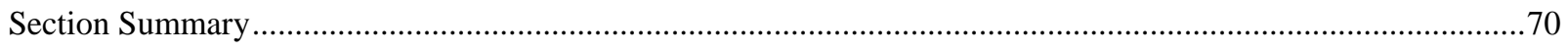

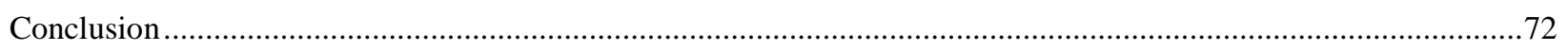

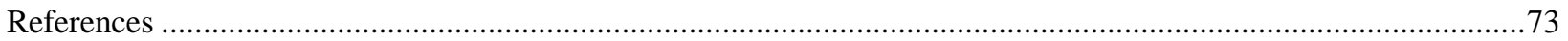




\section{Introduction}

"A merchant is accustomed to employ his money chiefly in profitable projects; whereas a mere country gentleman is accustomed to employ it chiefly in expense, "said Adam Smith. This statement echoes Henry Ford's sentiment when he was able to introduce the famous Model T at a price that the masses could afford by using technology and mass production. Today, his legacy leaves on, although on a grander scale. Ford is a global company with millions of customers spanning the globe. Still, globalization has upended the game and with it, increasing challenges for Ford, its competitors, and the industry. Undoubtedly, profitability for the company is slipping, and as gas prices increase the company wants to focus on trucks and sports utility vehicles that are not the most efficient vehicles, which means that they tend to lose market appeal with higher fuel prices, albeit the company has made efforts to improve efficiencies. This dichotomy can be a treacherous game for the company, an adequate alternative could be a recommitting to its roots of building cars that the masses can afford while continuing to satisfy the market's temporary appetitive for trucks.

\section{A1. Unit of Analysis}

This paper presents the potential strategic problems that stem from the symptoms shown by Ford Motor Company, a global automotive producer with millions of customers scattered all over the world. The company pioneered the concept of mass production, and in the process ushered automotive transportation to the masses. True to its origins, Ford has historically followed a broad approach to the market.

Moreover, the company was chosen for this analysis because previous experience with some of its affiliates provides valuable insight into the company and the industry. In addition, as 
one of the largest automobile manufacturers in the United States and the globe, its direction provides early indications of the industry and world economy.

\section{Strategic Problem}

Today, the future looks uncertain for Ford. The company has, for the most part, followed a broad product approach as its key strategy. However, under the direction of a new chief executive officer, it is shifting its strategy from selling many vehicle lines that include passenger cars (broad product approach) to one that focuses the production on sport utility vehicles and trucks (focused). The problem is compounded because while Ford focuses on a narrow market segment, its competitors work on filling the void. Thus, when the market recovers, or fuel prices increase Ford may be unable to dominate because its capabilities will be limited.

\section{Mature Industry}

It is paramount to recognize that the automotive industry is mature and until recently, a few large players cornered the market with their products while potential competitors stayed on the sidelines discouraged by its high entry barriers. However, Eric Lawrence from the USA Today (2018) reported that Ford's new CEO wants to change the company broad market strategy that includes passenger car manufacturing to one focusing on building more trucks and sport 
utility vehicles. This strategy can seem like a reasonable play as consumers preference in Ford's largest markets shits towards these vehicle types (Lawrence, 2018).

The problem with this new approach includes several elements. First, new passenger car sales are once again increasing in the U.S. and abroad (Figure 1). Second, electric vehicle sales, especially passenger cars, are also increasing (Figure 2). Although, it is also accurate that electrified automobile production represents a small percent of the automotive industry. Nonetheless, production increases are expected to continue. In fact, General Motors, Tesla,

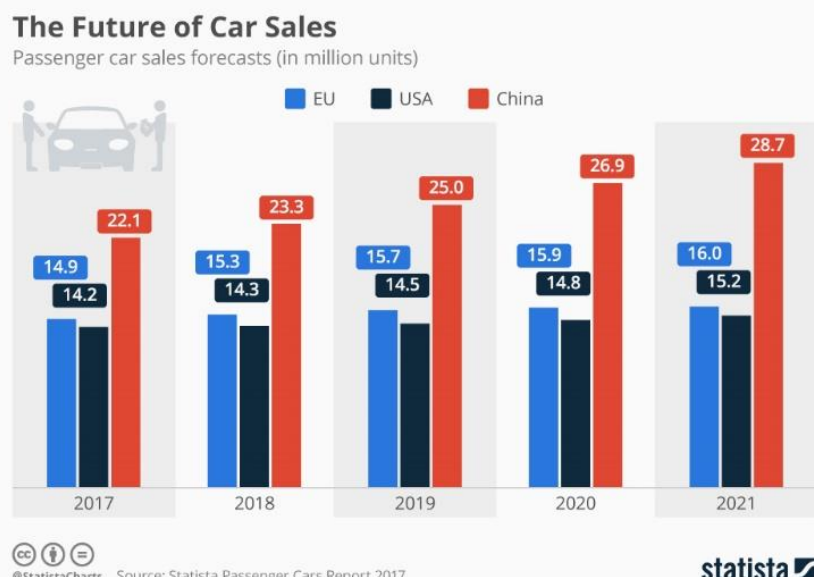
and few other competitors continue to release entry-level electric and semi-autonomous vehicles that fill Ford's market void (DeBord, 2018). Essentially, Ford's approach appears to be a reactive decision to a long game (Wheelen, Hunger, Hoffman, \& Bamford, 2014, p. 24). The takeaway here is that while Ford abandons a market that can't control, the void is being filled by its primary competitors, and it's also opening

Tesla Dominates The U.S. Electric Vehicle Market U.S. electric vehicle sales share (based on unit sales between January \& June 2017)

Tesla Model S T $\equiv 5$ L

Tesla Model X $T \equiv \Sigma L \bar{n}$

Chevrolet Bolt $\sum_{\text {chevrour }}$

Nissan Leaf

Fiat 500e

vW e-Golf

Ford Focus

Bмw із

Kia Soul KIN

Other

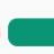
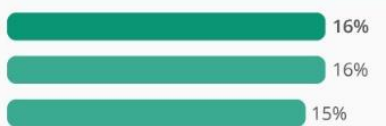

(it)

(14.1)

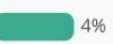

$2 \%$

8

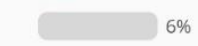
the door for new competitors.

\section{New Competitors}

Furthermore, the automotive

industry is quickly feeling the ripples

caused by new technological changes that include electrification of vehicles,

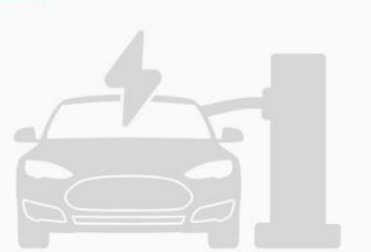

statista 
ridesharing, and autonomous driving. In addition, the industry is transforming as new entrants from other industries leverage information technology dynamics to gain a competitive advantage. Leading strategist and author Michael Porter (1996) said, "A company can outperform rivals only if it can establish a difference that it can preserve" (p.3). Yet, as a latecomer to these technologies, Ford's opportunity in these sectors is limited, while global enterprises like Apple, Google, and Tesla have embarked into a frontal attack against the automotive industry giants.

Furthermore, Tesla is a producer of high capacity batteries, and it is one of the top suppliers of electric batteries for the auto and other industries. But, the company also produces electric vehicles. Its vehicles are semi-autonomous and soon will be completely autonomous. This means that Tesla will compete as a vehicle manufacturer, but also as a substitute product because its autonomous vehicles will soon become the de-facto method of ride-sharing. This approach could end the need for vehicle ownership since quick, reliable, and individual transportation will be available by just summoning a vehicle with a cellular phone application.

\section{Financial Position}

We must first consider the fact that Ford's profitability is eroding, while its competitors have strengthened their financial position. The company's latest sales report states that its new vehicle sales are down over six percent (-6.6\%) from January 2017 with new passenger car sales down over twenty-three percent (-23.3\%) (Merkle, 2018). Furthermore, the company's recent credit downgrade by Moody's Investor Services (2018) stands as a clear warning sign for the company's short-term future (Moody's Investor Services, 2018).

On the other hand, Toyota and General Motors are experiencing significant increases in the fortunes. 


\section{Reasoning}

Today, the company needs to make a choice. The fact that strategic changes can lead to new markets is a well-known fact, but so is the risk of making incorrect assumptions. The advent of electrical vehicles is creating ripples in an industry long dominated by unions and traditional production methods. Whilst, new competitors, have completely skipped traditional retail channels by introducing direct and online sales platforms that bypass traditional dealer networks.

\section{A. Market Share}

At the same time, electrified vehicle sales have been steadily increasing for the past few years. Indeed, global electric vehicle sales are increasing and even though electric vehicle sales represent $1 \%$ of global market share today, the trend continues to climb (Statista). Tesla is the leader in this segment, and GM is closely behind while Toyota is not a significant player (Statista). Yet, Ford continues to command a small market on this segment. After all, Ford has been unable to achieve a process of "...rapid, ongoing improvement that draws the entire community toward a grander future" (Moore, 1993, p. 79). Although, it is safe to assume that its fiscal problems weight heavily on this issue. Overall, it is clear that Ford has failed to innovate and lacks the finances to gain market from its competition. 


\section{B. Questionable Strategy}

On the other hand, we must acknowledge Aristotle's words who said, "Nature abhors a vacuum. ${ }^{1 "}$ The same principle can be applied because the company's exit from the passenger car market will create a void that competitors will exploit since passenger car sales continue to increase globally, which means that Ford will find many challenges to become relevant in the future. Besides, as soon as fuel prices increase, the demand for higher fuel consumption SUV's will wane. In fact, other manufacturers are already experiencing record sales of their small electric passenger cars, yet, Ford is struggling to remain in the passenger car segment (DeBord, 2018). In other words, new competitors with electric / autonomous vehicles could dominate the market while the company is looking elsewhere.

\section{Profitability \& Innovation}

Ford does not have the profitability of its competitors, nor is it a market leader in the fast-growing segment. Profitability is up on the side of Toyota, while Ford's recent credit downgrade is indicative of larger problems in the near future (Moody's Investor Services: Global Credit Research, 2018). In fact, Toyota is considered by many one of the most profitable automakers today. Furthermore, Toyota has cut its production costs to increase its research and development investments (Buckland \& Sano, 2017). On the other hand, GM appears to be well poised to take the lead in the segment as it is in better financial position than Tesla, and it is ahead of Toyota in the use of emerging technologies (Assis, 2018). This means that Ford is ill-

\footnotetext{
${ }^{1}$ Nature fills every space
} 
prepared to offer the new products and services that customers, especially early adopters, will soon demand.

\section{Organizational Changes}

Finally, the company's intent to forgo mass-market vehicles, a dramatic turn from its origins, in favor of higher margin and lower production models is a risky venture. This shift has the potential to upend its dealer network because lower volume vehicles will reduce their supply of inventory for sale. Furthermore, this dramatic shift in direction also requires cultural, economic, and organizational restructuring, at a time when its competition is coming from nontraditional organizations. It is the equivalent of recreating a new company.

\section{Potential Solutions}

The company needs to stabilize its financial position quickly. In the short term, this will require some sacrifices. A realignment of its corporate, business and even functional strategies with market demands will be a step in the correct direction. Yet, the idea of abandoning a growing market, especially the segment that is expected to realize the most growth in the future is not an ideal approach. This measure appears to be merely a reaction to the issues, without much consideration to its potential consequences.

\section{A2. Strategic Audit}

\section{Strategic Problem - Current Situation}

The company's strategic shift from passenger car production to focusing on trucks and sport utility vehicles can be a double-edged sword because by reducing its presence in the passenger car segment, it is opening the door for new entrants and substitute products which are 
already filling the void. Furthermore, the industry is mature and tends to be cyclical, which means that the market will eventually swing back in favor of passenger cars when fuel prices increase or when new technology enters the market, like the new electrified technology models already in production by its competitors. All in all, it is a significant departure from the company's roots and it introduces major risks for the company and its stakeholders, because, while current market trends seem to validate the change, it is a shortsighted and reactive approach to a long-term problem.

Briefly, the company faces three main challenges. These are a significant increase in competition, the loss of market share with the consequential profit erosion.

\section{Increased Competition}

The recent and significant increase in the competitive forces that affect Ford, represents unprecedented challenges for the company. Ford's main competition usually came from GM, Chrysler, and Toyota, with the latter increasingly becoming its main foe. Today, a significant shift has occurred as increasingly competitors embrace the use of new technologies like electrified drive trains and autonomous driving. For instance, Tesla, the electrified vehicle provider, is now entering the passenger car market with an entry-level product that can easily take early adopters away from Ford. Yet, this is not the only manufacturer to produce an electric vehicle, as increasingly manufacturers shift their production to these new vehicles.

\section{Loss of Market Share}

Customer preference is shifting. The advent of electric vehicles is here to stay, and Ford is not a significant player in the segment. The investment firm, "Baird believes that Tesla could eventually sell more than 500,000 Model 3s annually. That would put it squarely among the 
nation's top-selling vehicles" (Marino-Nachison, 2018). This number does not consider the fact that companies like Toyota and GM are solidifying their position in this market.

\section{Profit Erosion}

Ford Motor Company, like many other automakers, has encountered economic losses during the past few years. Yet, Ford's situation is precarious as its stock gets negative marks from most investment analysts and the market favors more efficient competitors. This situation places the company in a difficult situation at a time when it should be investing in future technologies that could make or break the company in the future.

\section{B. Mission and Vision statements}

Since its genesis at the beginning of last century, Ford's mission statement has continuously evolved. In its latest iteration, the company promotes a vision, in lieu of a mission statement. It is, "People working together as a lean, global enterprise to make people's lives better through automotive and mobility leadership."

Now, this clearly shows Ford's ambition to remain an organization of global reach. It also shows the desire to be a "lean" enterprise. Yet, the concept of "making people's lives better through automotive and mobility leadership", is vague and potentially a challenging proposition to follow for most of its workforce. It appears that Ford wants to erase the lines between automotive and mobility products. The fact is that an automobile can be a mobility solution, yet a mobility solution does not necessarily mean that automobiles are involved, thus its business model is murky. In other words, it appears that Ford is moving away from what has been its core business of providing passenger cars to the masses. 

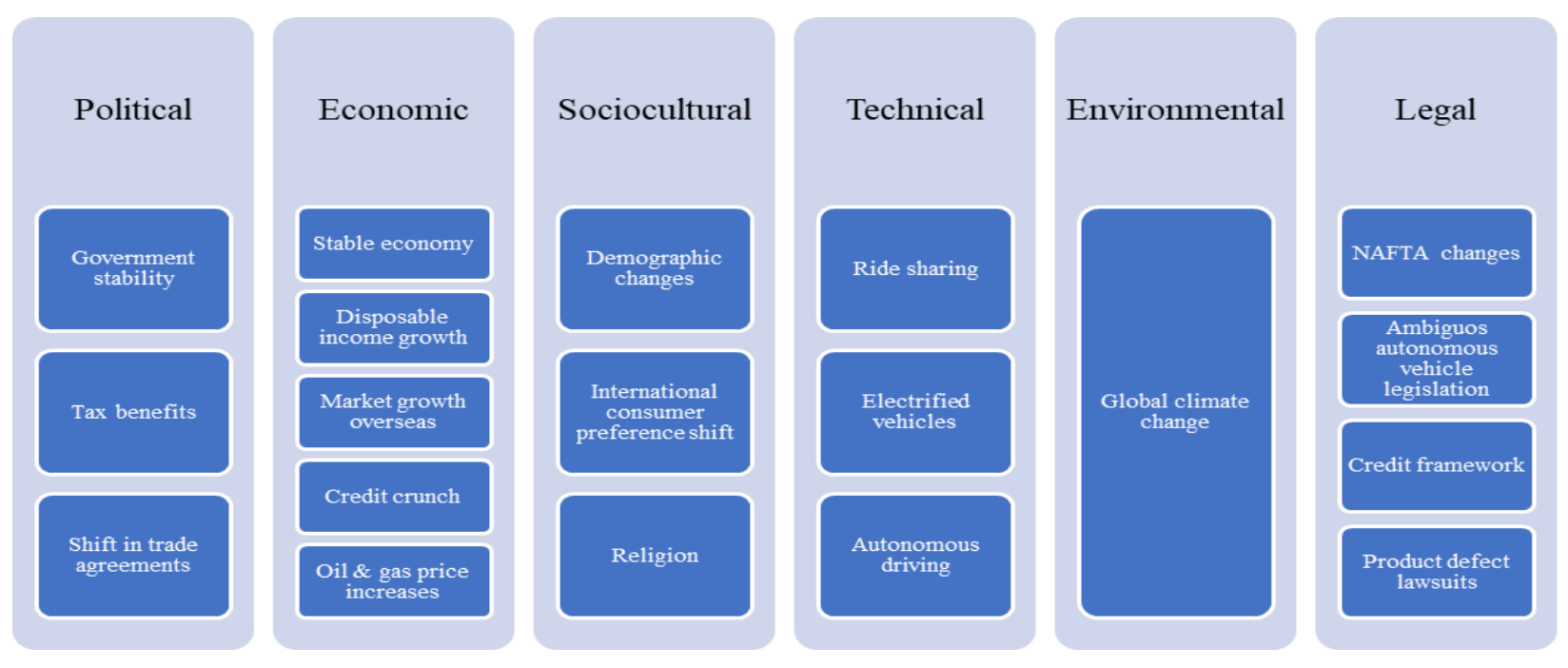

\section{PESTEL Analysis}

The following section includes a PESTEL Analysis (Political, Economic, Sociocultural, Technological, Environmental and Legal) to illustrate some of the elements that could affect the company, both in a positive and negative light (Figure 3). Clearly, Ford faces significant challenges, yet history shows that it is a very resilient organization.

\section{Political.}

The political arena seems favorable for the company despite its previous, and well-known quarrels with the president of the U.S. The tax reform and governmental stability are positive elements, while the potential trade policy changes can suggest future challenges for Ford.

\section{Governmental Stability.}

The company will certainly benefit from the political stability in China, Europe, and North America, although its spats with president Trump are a detraction. 


\section{Taxation.}

The recently enacted U.S. tax reform can be favorable for the company because it ushers in a lower tax liability for the company. Furthermore, it allows the company to repatriate much of its overseas profits at a lower cost. This change will result in a lower tax payment for the manufacturer. Albeit, these payments will be reduced by the company's “deferred tax assets by being unprofitable in the U.S." during the fiscal crisis of the previous decade, making the effective tax rate similar to last year (Butters, Welch, \& Naughton, 2018).

\section{Trade Policy.}

The change in U.S. trade policy can spell troubles for the company because I could lead to increased production costs. For instance, the cancellation of TPP agreement on the part of the U.S. president cuts a potential benefit by fencing certain trade partners.

On the other hand, the recent and continuous political differences between China, Russia, and the United States are not expected to grow past the present stages because an escalation on any part will bring significant economic troubles for all the parties involved.

\section{Economic.}

The US economy seems favorable for the company, especially after the recently enacted tax reform is implemented in the US. Overall, most economic indicators show a significant growth of the U.S. economy.

Furthermore, current trends suggest that the significant increase in real disposable income will continue (Figure 4). 
However, low unemployment levels in the U.S. may lead to an increase in human resource costs for Ford, albeit the company uses a machine and automated production which could limit this cost. Conversely, unemployment levels are much higher in the Eurozone (The Economist Editorial Unit, 2017). All in all, the combination of a lower tax rate, an increase in disposable income, and a growing economy suggests an increase in the company's fortunes.

Furthermore, Ford can expect significant growth overseas after achieving record sales in 2016 in China. According to a 24/7 Wall Street (2018) article, the company reflects a remarkable 2017 as indicated:

Ford's fastest growing sales regions are the Confederation of Independent States (former Soviet Union republics), where sales are up more than $15 \%$ to 50,630 units, and the Association of Southeast Asian Nations (ASEAN), with sales growth of more than $12 \%$ to total 117,725 units

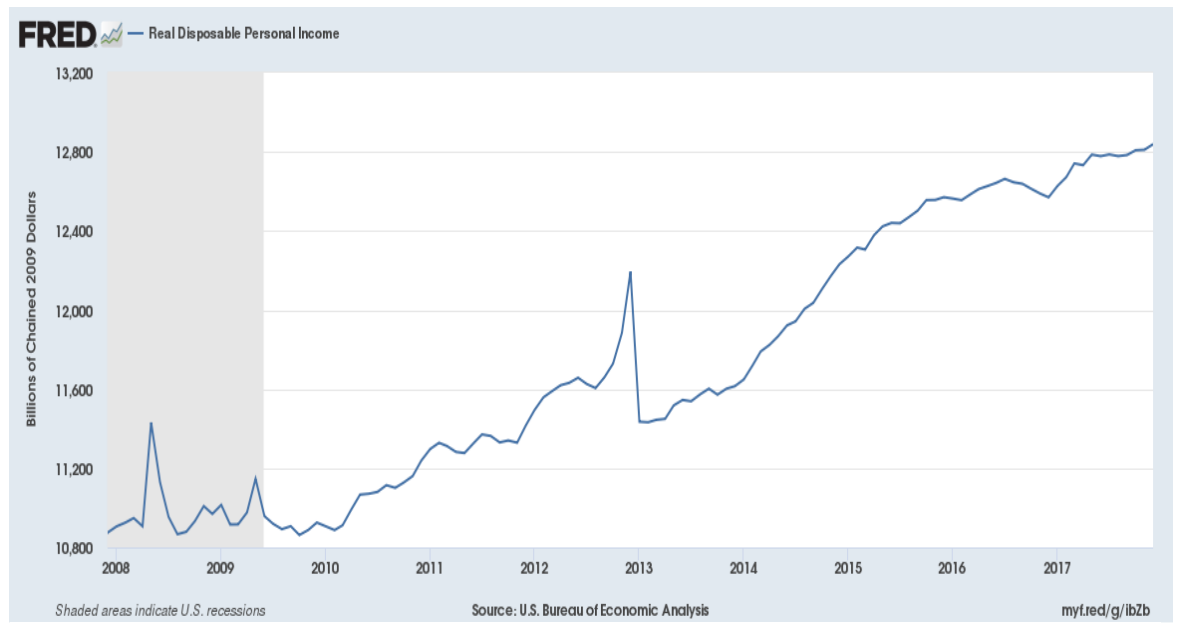

(Ausick, 2017).

\section{Overall, China}

continues to show strong growth, a path that appears to continue. On the other hand, the following elements play paramount roles in the industry: 


\section{Credit.}

The main challenge faced by the company is the era of economic growth is the issue of credit. In the United States, the pool of qualified applicants continues to dwindle; in part, a consequence of the recent economic downturn faced by the populace. It is not a secret that the previous financial crisis left many customers with blemished credit reports. This element is reflected in a sharp delinquency increase of subprime customers(Tempkin, 2017). This could be challenging as the auto industry extensively relies on subprime credit to sell pre-owned vehicles, usually traded in for new ones and entry-level models.

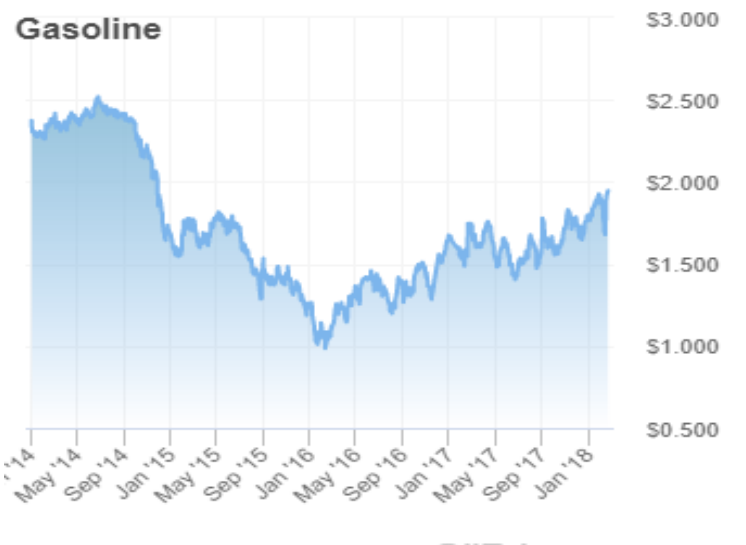

OllPrice.com

\section{Oil/ gasoline prices.}

These key factors have a profound effect on the sale of new vehicles, especially trucks and sport utility vehicles. In this case, the price of oil and gasoline are stable, albeit gasoline shows a tendency to increase in the future (Figure 5).

Fortunately, the company has added several fuelefficient sport utility vehicles, which are now its main staple.

\section{Sociocultural.}

The sociocultural element for Ford presents some challenges, as demographic changes take place across the globe. The bulk of the US population is the group of individuals under 18year-old, followed by those over 65 years old (U.S. Department of Commerce, 2016). This medley presents challenges and opportunities. On the plus side, the group under 18, will be close to its buying age and may consider some of Ford's entry-level passenger cars, if the company 
continues in the market. This is the challenge because traditionally, sport utility vehicles and trucks are higher priced vehicles, and out of the reach of first-time buyers. On the other hand, the baby boomer generation might benefit, from the fully autonomous vehicle proposed by the company in the near future.

Internationally, consumer preference is opaque. First, the relationship between brand, country of origin and customer preference can hinder the brand's growth (Wang \& Yang, 2008. p.459). After all, the new political position of the US has proven to be unpopular in some of the world's largest markets.

However, it is a well-known fact that religion plays a prominent role in the Middle East, to the point that women are forbidden from driving vehicles. This cultural element can represent a tremendous benefit for a company producing autonomous vehicles because the women will not need a driver to conduct their daily affairs. Yet, Ford is behind on this technology, even when some studies may suggest otherwise (Kendall, 2017). The fact is that at this time Ford does not have a fully autonomous vehicle and its best estimate is that it will have one by the year 2021(Ford Motor Co., 2015). That is three years away, under a best-case scenario, yet, Tesla's autopilot system is functional today and fully capable of autonomous driving, although not yet approved by U.S. federal regulators.

\section{Technological.}

The most important technologies driving the automobile industry are ride-sharing, vehicle electrification, and autonomous driving. Yet, Ford is behind in all of them.

First, Uber and Lyft have a dominant position in the ride-sharing industry, while Ford's attempts to enter this market with its Ford Smart Mobility LLC and the acquisition of Chariot, 
which is floundering with a minuscule market presence (Ford Motor Co., 2015, p.6). In contrast, “Uber Technologies Inc Chief Executive Officer Dara Khosrowshahi said on Tuesday he can see commercialization of the Uber Air flying taxi service happening within five to 10 years"(Reuters Staff, 2018), while Ford attempts to enter the ride-sharing market.

Furthermore, the electrification of vehicles is driven by Tesla Automotive and closely followed by Toyota and GM with their hybrid vehicles. In contrast, Ford is struggling with its attempts to market its Ford Fusion mid-size sedan.

Finally, the leader in autonomous driving is Tesla Automotive, followed by European brands (Audi, BMW, and Mercedes) that have introduced significant features in their products. Actually, some of their products are considered semi-autonomous. In contrast, Ford is limited to parking assistance in a limited number of models.

Briefly, Ford's ambition to produce a fully autonomous electrified vehicle by the year 2021 seems like wishful thinking, especially when its competition is so far ahead.

\section{Environmental.}

The environmental element plays a prominent role in today's globalized economy. Global climate changes taking place today forces companies to look at better ways to care for the planet. For instance, Ford has made significant strides to produce more efficient vehicles, including the use of aluminum bodies in its bestselling F-150 truck, a measure designed to build a lighter truck with increased fuel efficiency that reduces $\mathrm{CO} 2$ emissions and minimizes the use of fossil fuels. Similarly, the company continues to deliver hybrid vehicles with increased fuel efficiency. 
Yet, fuel efficiency is not the only element at play in the environmental arena. The increase in weather-related challenges, like the 2011 tsunami in Japan that forced Toyota to halt production, can wreak havoc on the company's supply and distribution channels affecting profitability and market share (The Economist, 2011).

Consequently, Ford continues to embrace a culture of corporate sustainability responsibility. Ford is “the only North American consumer discretionary company to earn CDP's highest honor for corporate water stewardship", and has also implemented a significant reduction of CO2 emissions and energy usage (Ford Motor Co., 2015, p.6).

Overall, Ford keeps an adequate position on environmental issues, although its disaster preparedness plans are unclear.

\section{Legal.}

The main challenge today is the future of NAFTA (North America Free Trade Agreement) which is questionable at this stage since the president of the U.S. is concerned with its viability. Therefore, the impact on the auto industry and Ford is also uncertain. Yet, the company may be forced to source new suppliers which could change its production and profitability.

Moreover, the regulatory framework for the autonomous cars that Ford intends to produce in the future, is in a nascent stage. This means that Ford and its competitors must be flexible and prepared to adapt or contribute to a legal framework under development, with all the uncertainties associated with this stage. 
Also, as the company expands its presence in the Far East, it is important to note that the region lacks an adequate legal framework for credit transactions. This means that once the pool of cash buyers dwindles, market growth could reach a plateau unless appropriate steps are taken. Furthermore, the potential changes faced by the company as the country's presidency takes a new direction on trade policy are unknown at this time.

On the other hand, in 2016 the company was named as a defendant in many lawsuits seeking damages for alleged product defects (Ford Motor Co., 2015, p.20). Similarly, the company is a defendant in lawsuits claiming asbestos exposure, yet the status of these claims is unknown today (Ford Motor Co., 2015, p.20). This illustrates the difficulties faced by the company (and its competitors) planning for unforeseen events, especially those that may involve supplier negligence.

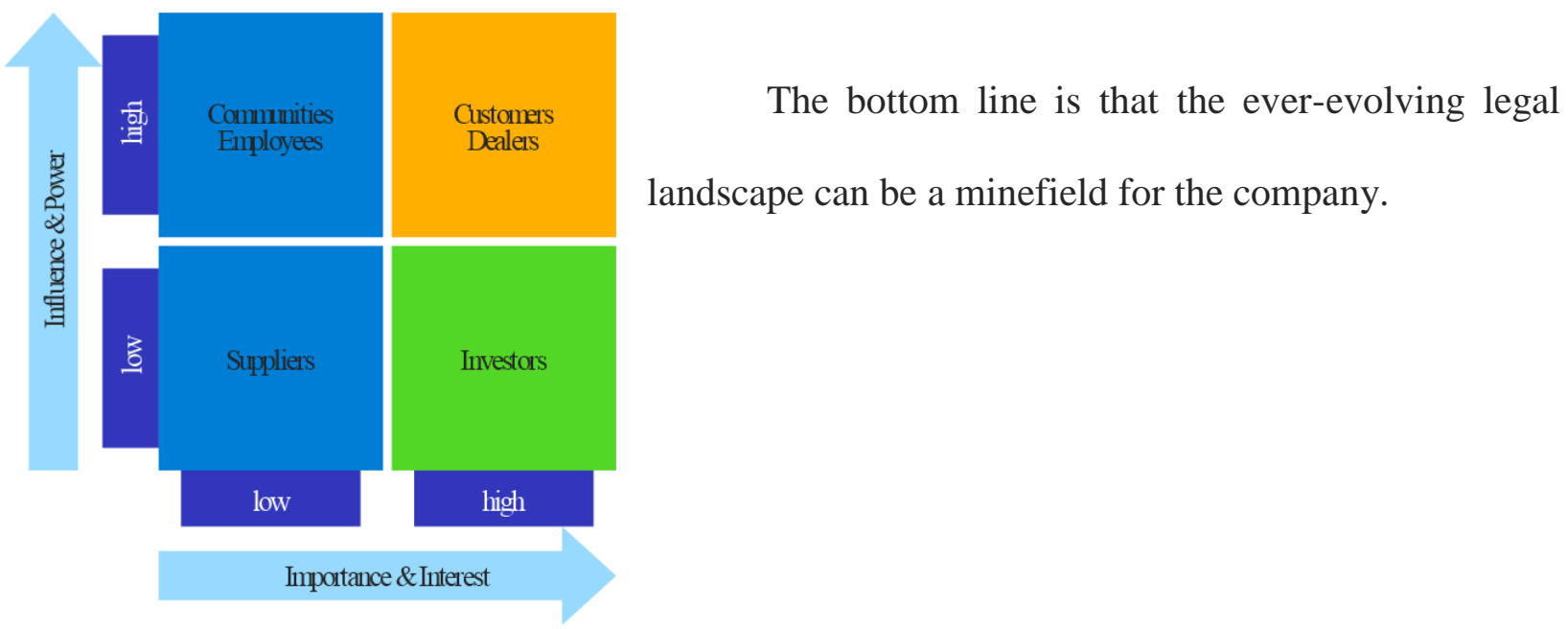

\section{Stakeholders Analysis (Figure 6)}

Ford Motor Company, in its 2016/17 Stakeholder Engagement Report list the following groups as its key stakeholders: 
Communities: This segment includes both government and NGO organizations. The company states that it is present in more than 100 countries across the globe.

Customers: The company reports sales of more than six million six hundred thousand $(6,600,000)$ vehicles.

Dealers: A total of 11,737 dealers compose Ford's dealer network across the globe

Employees: Globally, Ford Motor Company employs more than two hundred thousand employees. In the US. many of its employees are unionized.

Investors: At the time of the report, Ford had over one and twenty-five thousand $(125,000)$, investors

Suppliers: Ford claims total sources in excess of one hundred and ten billion dollars.

The company's vision clearly defines the customer as its main stakeholder group, closely followed by its employees and dealers, since they help with the company's vision. Furthermore, without customers, the company's existence becomes irrelevant. However, it is necessary to also consider the role played by the communities (including regulatory agencies) in the company's future because this stakeholder group can exert significant influence on the company. Yet, as a global company, it can always move its operations to more favorable locales, which given the size of the company may not be an adequate move, but, it is indeed, a possibility. 


\section{ii. Business Sustainability}

\section{Porter 5 Forces \& Key Success factors}

The automotive industry has always relied on efficient production, technology and

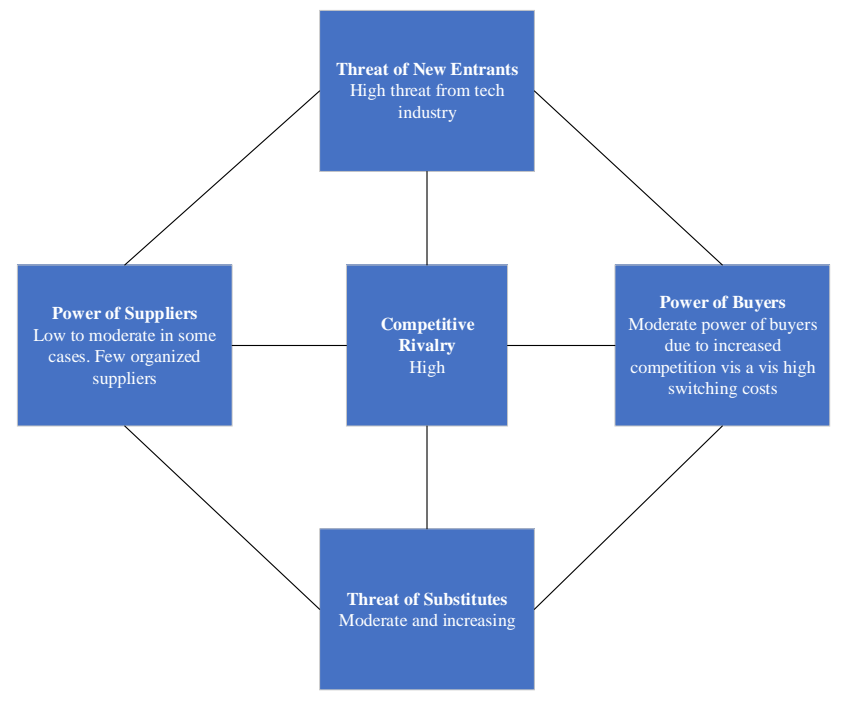

Figure 7 Five Forces

manpower for the effective production of vehicles. In addition, top manufacturers need a welloiled dealer network that supports the company's sales and service efforts.

On the other hand, the Five Forces analysis is summarized in figure 7.

\section{The threat of New Entrants.}

Until 2010, the threat of new entrants to the auto industry was low because the high barriers to entry kept most at bay. But, "Back in 2010, Tesla became the first publicly traded carmaker to emerge in the U.S. in 54 years. Now its market value rivals Ford and General Motors,"(Randall \& Halford, 2018). Actually, Tesla's main problem today is that with over 500,000 waiting orders it cannot build its new Model 3 fast enough. At the same time, well capitalized and profitable technology companies have taken note of Tesla's success and are pondering a market entry. These new potential entrants bring significant resources, like capital, 
information technology and considerable amounts of data to the table. The sum of these elements suggests that Ford will face increased pressure from new entrants elevating the threat of new entrants to high levels.

\section{Power of Buyers.}

Ford customers exert moderate to high pressure on the company's future. First, competition abounds from other manufacturers, which forces Ford to remain competitive and maintain a high degree of customer satisfaction. A change in market preference or failure to consider these elements can easily send customers to the competition. This effect can result in significant profit erosion for the company. On the other hand, switching cost on vehicle purchases can be high since vehicles are big-ticket items.

\section{Power of Suppliers.}

As a global company, Ford sources from many suppliers across the globe. Many of the suppliers come from different locations and produce many different products. In other words, there is not a single group or location that associates all the company's suppliers. Albeit, some of them have a long-standing relationship with the company. This suggests that most suppliers are not organized, resulting in a weakened power base. Furthermore, Ford sources billions of dollars every year which means that its bargaining power is high. Additionally, Ford's own internal factories, like the River Rouge Plant - one of the world's largest, can produce many of the parts needed for automobile manufacturing, albeit, this may not be an adequate solution for overseas production. 
However, many of the company's employees are members of the United Autoworkers Union, making the union an influential supplier to the company. In other words, supplier power is low, and moderate in some limited cases.

\section{The threat of Substitutes.}

The auto industry didn't use to have many substitutes. Yes, mass transit can be considered a substitute for an automobile, but its limited service served as a limit to its reach. Yet, today market dynamics are changing. The rise of ride-sharing services is changing the way that individuals view the purchase of an automobile. Today's consumers can summon reliable and affordable transportation with one of several competing services. While services like Uber and Lyft rely on drivers with automobiles, the new dynamic means that one driver can serve many customers. This translates into potentially lower vehicle sales for Ford. The problem will be further compounded once Tesla and several other manufacturers increase the production capacity of their fully autonomous vehicles because these robot vehicles will be available at the signal of a customer's phone. This will hurt the company's long-term viability. The message for Ford is that the threat of substitutes is moderate and expected to increase.

\section{Competitive Rivalry.}

It used to be that the auto industry in the United States had a few competitors. But, today that is changing. In addition to the big three (Ford, GM, and Chrysler) in the U.S., the industry has many competitors, both local and from abroad. In fact, Toyota, and Volkswagen lead the charts in terms of global revenue (Figure 8). 
Furthermore, most of the Asian

and European brands now have

production in the US and in almost

every country where Ford is present

which may erase any currency

advantage for the company. Soon,

Chinese companies will also join the

competitive arena.

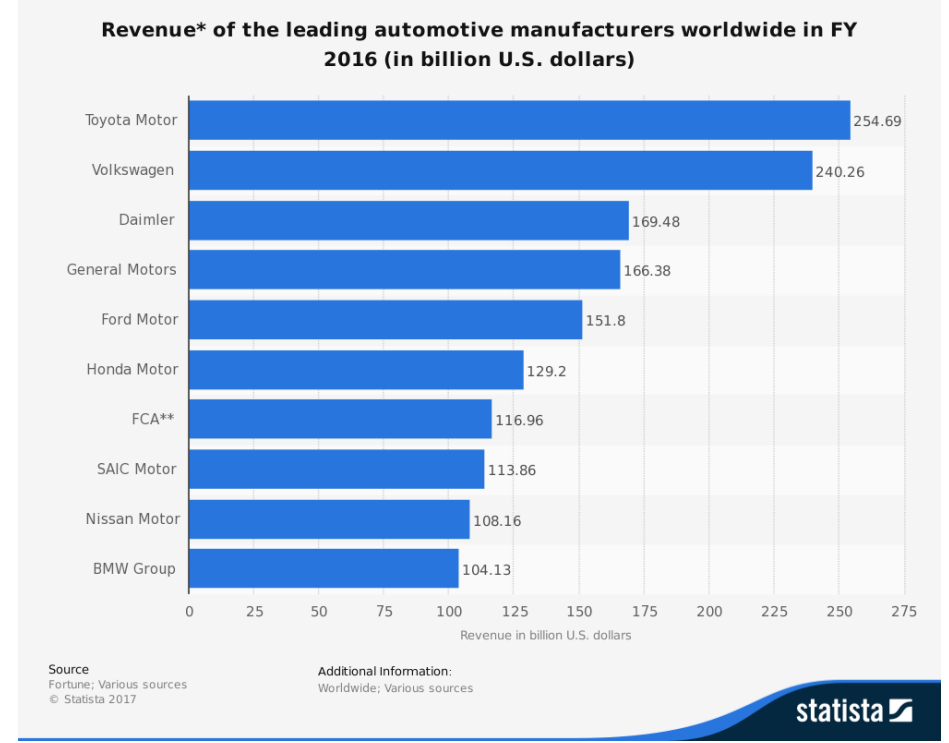

On the other hand, Tesla and

several other new electric vehicle

manufacturers have entered the market, heating up the competition in the process. The problem

(for Ford) is that these new competitors are well capitalized and bring significant technological breakthroughs to challenge Ford and many of the industry giants.

These elements suggest a high degree of competitive rivalry.

\section{B. Financial Analysis}

Ford Motor Company's financial data is compared with Toyota Motors, its fiercest competitor, and with Tesla Automotive because it represents the future of the auto industry. The data reveals a company (Ford) with large revenues, yet not as profitable as Toyota, its main competitor. Furthermore, Ford shows that it is losing consumer preference while Tesla - a newcomer to the market - shows tremendous growth. 


\section{Cash Flow \& Profitability.}

As an established global company, Ford's cash flow from operations is significant. In fact, as shown in table 1, it easily dwarfs Toyota and Tesla combined. Furthermore, the company shows an increasing revenue trend, and it just reported its best sales level in China (Ford Motor Co., 2015). Nonetheless, the company has not generated the net income levels of Toyota, nor has it been able to meet Tesla's 22.8 percent (\%) or Toyota’s gross profit margins (Figure 9). Indeed, clearly Tesla benefits from early adopters of its novel products, and Toyota from earning some of the highest levels of customer service in the market, yet, Ford is an established company with a significant brand equity that is trailing the profit levels of the others. It is also significant that all

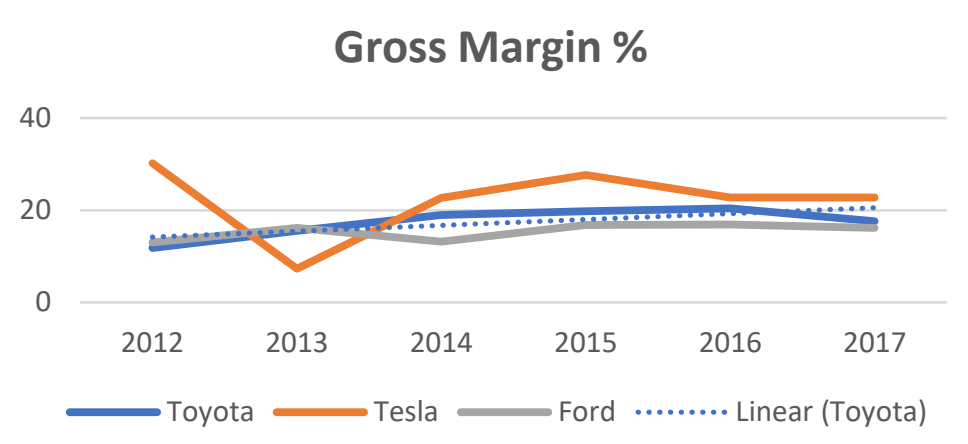

\author{
three of these organizations have a \\ similar cost of goods sold (COGS) \\ which suggests that customers are \\ willing to pay a premium for \\ competing products.
}

On the other hand, Ford's

return on equity (ROE) has shown to be consistently higher than the others.

\section{Leverage.}

As a new company, Tesla shows high debt ratios. Nonetheless, over the past 5 years, Ford's positioning reveals higher debt levels than Tesla and Toyota. Its debt to equity ratio of 3.2 in 2016 is much higher than Toyota and Tesla combined. This suggests that Ford has been borrowing for its recent acquisitions, to finance growth or to cover expenses during the difficult times that it has met. It could also be the result of slower sales causing an increase in inventory 
levels (slow inventory turnover), which are not producing revenue. A detailed financial analysis, which is outside the scope of this paper, is required to determine the exact cause of this issue.

On the other hand, Ford's current ratio or the assets available to cover existing liability fares similar to the rest, albeit for the past five years it has been slightly higher than the rest.

\section{Efficiency \& Growth.}

In 2016 Ford showed an inventory turnover ratio of 14.7 Conversely, Toyota and Tesla show rates of 10.77 and 3.23 respectively. The problem is that Ford's ratio shows a decreasing trend for the past five years, while Toyota seems to maintain its level. This suggests that Ford is losing the favor of its customers as it suggests weaker sales leading to an increase in inventory levels.

Moreover, Tesla shows the most dramatic growth (year over year). At 102.76 percent $(\%)$, it shows a company that is rapidly gaining market traction. This is paramount because the company continues to have a backlog of close to half a million customers waiting for their Model 3 passenger car to be delivered. In addition, its upcoming sports car is also gaining significant accolades from the press, which the company is quickly turning into cash deposits and future sales.

On the other hand, Toyota is also showing greater growth than Ford. For the past five years, the company has grown many times Ford levels, to the point that in 2017, Toyota reported growth in excess of eight percent, while Ford was slightly above three percent. 


\section{Other.}

It is important to realize that even though Ford is an established company, with substantial brand equity, the market views the company as less valuable than its competition. In fact, according to NASDAQ (2018) reports, Tesla's 59.1B represents a much higher market value than Ford, GM, and Fiat Chrysler. Furthermore, Ford's valuation at $41.7 \mathrm{~B}$ is lower than GM's but higher than Toyota's 3.2B (NASDAQ, 2018).

On the other hand, Table 1 summarizes the data showing Ford with a .94 market beta, which is lower than the rest with the exception of Toyota's .81 (NASDAQ, 2018). In comparison, Tesla has a beta coefficient of 1.13, which even though it is higher than Ford it accurately reflects the market perspective on the company (NASDAQ, 2018). This says that the market sees Ford as a lower than average risk, and a stock with minimal volatility. Tesla's volatility, on the other hand, appears to be the result of its difficulty meeting production goals for its new model 3 , the fact that it has no recorder a profit since it is a new company, and the continuous borrowing to finance expansions.

Table 1(Source NASDAQ, Data on 25 Feb 2018)

\begin{tabular}{|c|c|c|c|c|}
\hline Company & Tesla & GM & Ford & Toyota \\
\hline Beta Coefficient & 1.13 & 1.08 & .94 & .81 \\
\hline Market Value & $\$ 59 M$ & $\$ 57 \mathrm{M}$ & $\$ 41 \mathrm{M}$ & $\$ 3 \mathrm{M}$ \\
\hline
\end{tabular}

\section{Competitive Analysis}

Today, several large manufacturers and few newcomers dominate the automobile industry. 


\section{Pricing.}

In the case of Ford, the pricing of its broad product line is matched by General Motors, and Toyota, it is also closely followed by Fiat Chrysler. Although, it appears that Toyota is able to maintain its prices better than the rest. Admittedly, the market preference continues to be the focused-on truck sales, a segment that composes over $60 \%$ of the sales in 2016. In truck sales, Ford continues to dominate with its F series truck, which has been the number one selling truck in the US for many years. Although, many consider the statistic flawed because GM splits its truck sales between the Chevrolet and GMC brands.

The market segment also includes some smaller players. For instance, Honda sells to a smaller niche market using the "strategy of concentrating on product quality and careful customer targeting" a plan that has worked well for the company as it is one of the few companies that experienced growth in 2017 and its CRV small sport utility vehicle continues to dominate the sales chart(Trefis Team, 2017). Hyundai and KIA attempt to present value-added products, which are products with similar prices, but with more features.

In contrast, Tesla's products are targeted to the early adopter crowd and priced at the top of the pricing spectrum. The company produces the Model X, a fully electrified and semiautonomous sports utility at the higher end of the pricing spectrum.

On the other hand, the passenger car market continues to be challenging for these manufacturers, even with the release of new products by all. Here lies the problem for Ford and the rest. Tesla has a backlog of 500,000 orders for its new small passenger car, while Ford, GM, and Toyota continue to struggle with their respective product line. This suggests that these companies are in tune with the market demands. 


\section{Product Lines.}

Ford, GM, Toyota, and Fiat-Chrysler, albeit to a lesser degree, have very similar product lines. For instance, Ford sells the Taurus, aimed at the mid-sized market, while Toyota sells its bestselling Camry. GM sells the Impala and Fiat Chrysler the Dodge Charger, Chrysler 200 models. Nonetheless, Toyota also aims the Camry as a competitor to the Honda Accord and Nissan Altima.

In total, Toyota (Global - excluding Lexus) has over 70 models in its product lineup(Toyota, 2012). In contrast, Ford's lineup includes (Lincoln not included), 7 Passenger cars, 7 Crossovers/Sport utility vehicles and 5 Trucks (Merkle, 2018; Ford Motor Co, 2018). It is, however, necessary to say that most of the lineup includes many models of the same product. For instance, the Ford Super Duty line includes the F250, F350, F450, and F550. However, in this segment of heavier trucks, GM, and Fiat Chrysler are the only ones that offer competing products.

The case of GM is distinct because the company has several brands selling the same products albeit re-badged to target specific segments.

Outside of traditional automakers, Tesla embodies the future of the automotive industry with its limited product selection of few models. The company is only focusing on specific market segments, but its entry into the small passenger car market will target Ford and Toyota customer base. 


\section{Internal Analysis - Value Chain}

The company names the following elements as part of its value chain: Product Design, Raw Material Extraction, Logistics/Transportation, Supply Chain Parts Manufacturing, Ford Manufacturing, Sales and Service, Our Vehicles in Use, End of Vehicle Life(Merkle, 2018; Ford Motor Co, 2018). Overall, the extensive use of technology links and strengthens the interrelation of primary and support activities.

\section{Primary Activities.}

The company's primary activities include logistics (inbound and outbound), raw material extraction, manufacturing, sales, and service which includes the end of life management for its products.

\section{Logistics/transportation.}

Ford has a relationship with Penske Logistics for its North American operations in a process that centralizes all of Ford's logistics operations under one umbrella. This arrangement continues to create synergies that result in increased efficiencies for the company, including more efficient billing, reduce costs and greater transparency of its logistic operations (Penske Logistics, 2015). This novel arrangement is advantageous for Ford, yet it is easily replicated by its competition.

\section{Raw material extraction.}

As an industrial manufacturer, Ford sources raw material from many parts of the globe. The company keeps an ample list of suppliers for this phase, yet it is not the only manufacturer seeking the same material. Where Ford is making a difference is in the company's efforts to 
increase the level of recycled material, which translates into a reduced dependence of raw material extraction. Incidentally, this approach suggests a high level of corporate responsibility.

Moreover, the recently enacted tariffs on steel and aluminum have the potential to create a negative impact on Ford sales, especially if the European Union and China decide to counter the U.S. position, with its own set of retaliatory measures. At the time of this paper, the issue is under consideration for potential exemptions (Shepardson, 2018).

\section{Ford Manufacturing.}

This is a key element for the company because the company's public position is that its partnership with the United Autoworkers Union is paramount to its success. This level of collaboration is unusual, and a potential advantage for the company because the domestic auto industry has long suffered from conflicts and strife between corporations and union creating disruptions and profit erosion.

On the other hand, the synergy between manufacturing and human resources, technology, and the company's highly capable procurement system is advantageous because this level of coordination and collaboration requires precise equipment, unequivocal systems, and very capable individuals to operate. This is enhanced by the company's centenary experience in the industry.

\section{Sales and Service.}

The company is one of the world's largest automobile sellers. Its dealer network is comprised of 11,737 dealers(Ford Motor Co., 2015, p.2). This network includes some LincolnMercury dealers, usually are paired with a Ford franchise. Nonetheless, this large dealer network 
suggests a significant advantage by providing the company with a significant footprint in most markets across the globe.

On the other hand, as part of its approach to increasing sales, the company is looking to introduce a new credit decision system that will look past traditional credit scores without adding risk (Andriotis, 2017). The key element here is that Ford, like some of its competitors, owns its financing arm, to ease sales.

Toyota, on the other hand, has eight (8) overseas distributors and each one is responsible for the dealer network in its respective country (Toyota, 2012). In addition, the company operates dealerships in Japan. "As of the end of Dec. 2017, Toyota conducts its business worldwide with 51 overseas manufacturing companies in 28 countries and regions. Toyota's vehicles are sold in more than 170 countries and regions"(Toyota Global Newsroom, 2018).

Conversely, the area of sales and service is the area most likely to see forthcoming change, as Tesla promotes a successful direct sales method, where the traditional franchised dealer does not have a place. This approach gives Tesla more control of the overall customer experience, while maximizes its profits. However, this approach requires substantial capital resources that the company has been able to attract.

Overall, Ford believes that it represents the future of mobility and that its dealer network will adapt to the changes (DeBord, 2017). 


\section{End of Vehicle Life.}

The "end of vehicle life" is important because the company continues to increase its use of recycled material (Ford Motor Company, 2015). This requires a close relationship with the technology development, and it can be socially advantageous for the company.

\section{Our Vehicles in Use.}

This is part of the shift in corporate strategy towards becoming a mobility solutions provider.

\section{Support Activities.}

As a global company, Ford sources many billions of dollars per year in supplies, yet it is not the only company operating at this level. Its main competitors GM and Toyota also very effectively manage global supply chains. Moreover, it is clear from Ford's lackluster financial results that the company has been struggling with profitability (Waldemeir, 2017). The combination of these elements suggests that Ford does not have an advantage in this segment.

Furthermore, one of the weakest areas in the case of Ford is the development of new technology for electrified and automated vehicles. This is paramount because as electrified vehicles gain market share, consumers will demand fast and convenient charging for their vehicle. Tesla is ahead of this game because the company has already installed thousands of charging stations through the US for its customers, and it is following a similar approach overseas. In fact, these charging stations are a common sight through the US highways.

On the other hand, Ford has extensive research facilities that have produced market leader products, like the F series truck and the popular Ford Explorer. This suggests a strong 
linkage between its primary and support activities. This linkage is stronger between marketing/sales and technology (product) development areas.

Indeed, Ford has been successful in achieving economies of scope by designing products that can be resold in different markets across the globe. Furthermore, many of the company's vehicles are also sold under its Lincoln luxury brand. For instance, the popular Ford Edge sports utility vehicle is also sold as the upscale Lincoln MKX. This is accomplished by introducing various trim levels on common vehicle platforms to accommodate market and segment preference. The key takeaway here is that Ford has managed to benefit from its product design know-how.

Also, the company has publicly credited the United Auto Workers union for its success after the last financial crisis that drove General Motors to bankruptcy court, while Ford did not receive any government aid and managed to come out of the crisis without significant losses. This says that Ford has a distinctive advantage in the human resources area.

\section{Capabilities \& Core Competencies.}

Ford Motor Company has access to several tangible and intangible resources including:

\section{- Tangible Resources}

- Financial stability

- Physical (Global distribution, manufacturing, and sales centers)

- Significant Technological infrastructure

\section{- Intangible Resources}

○ Human

- Innovation (aluminum F series) 
○ Reputation

- Organizational \& Logistics efficiency

○ Patents

\section{- Capabilities}

- Vehicle Assembly/Manufacturing

$\bigcirc \quad$ Logistics management

○ Human Resources Management

○ Information technology management

\section{- Core competencies}

- New product development

- Brand recognition

○ Truck manufacturing

○

\section{VRIO.}

The VRIO analysis of Ford Motor Company reveals that Ford's main or sustained advantages are its very strong brand reputation and the relation with its customer base (Table 2). These two elements are the result of being at the forefront of the automobile industry for over one hundred years, which makes them very rare and almost impossible to imitate.

Moreover, the company enjoys a strong financial foundation, even though, lately its fortunes have seen a downward spiral. However, Ford has the capability to overcome this temporary setback. Moreover, while Ford owns and operates valuable facilities and produces some unique and innovative products, these elements are not unique to the company. While the company promotes the new aluminum body construction for its trucks as an advantage, sales 
volume speaks to the contrary, because the new product is only enjoying the expected sales increment for being a new model. Furthermore, while the company runs a very efficient operation, and enjoys strong relations with its channels and suppliers, competitors like Toyota and GM have raised their efficiency and productivity. Overall, it is safe to consider these elements as paired (parity) because most of its competitors have similar resources.

On the other hand, Ford used to have an effective management team in place, but the recent financial results and the shakeup at the top of the echelon suggest that this effective management is in jeopardy. All in all, at this point the company's management appears to be a disadvantage. 
Table 2 VRIO

\begin{tabular}{|c|c|c|c|c|c|}
\hline Resources & Value & Rarity & $\begin{array}{l}\text { Unable } \\
\text { to } \\
\text { Imitate }\end{array}$ & Organized & $\begin{array}{l}\text { Competitive } \\
\text { Advantage }\end{array}$ \\
\hline 1.A Strong Financial Foundation & $\mathrm{Y}$ & $\mathrm{N}$ & & & Parity \\
\hline 2. Valuable Facilities & $\mathrm{Y}$ & $\mathrm{N}$ & & & Parity \\
\hline 3. Unique and Innovative Products & $\mathrm{Y}$ & $\mathrm{N}$ & & & Parity \\
\hline 4. Effective Management & $\mathrm{N}$ & & & & Disadvantage \\
\hline 5. Experienced and Capable Employees & $\mathrm{Y}$ & $\mathrm{N}$ & & & Parity \\
\hline 6. Strong Relationships with its Customers & $\mathrm{Y}$ & Y & $\mathrm{Y}$ & $\mathrm{Y}$ & Sustained \\
\hline 7. Strong Relationships with its Suppliers & $\mathrm{Y}$ & $\mathrm{N}$ & & & Parity \\
\hline 8. Strong Relationships with its Channels & $\mathrm{Y}$ & $\mathrm{N}$ & & & Parity \\
\hline 9. A Strong Brand Reputation & $\mathrm{Y}$ & $\mathrm{Y}$ & $\mathrm{Y}$ & $\mathrm{Y}$ & Sustained \\
\hline 10. Efficient Operations & $\mathrm{Y}$ & $\mathrm{N}$ & & & Parity \\
\hline
\end{tabular}




\section{iii. SWOT}

The summary of the findings is shown in figure 4.

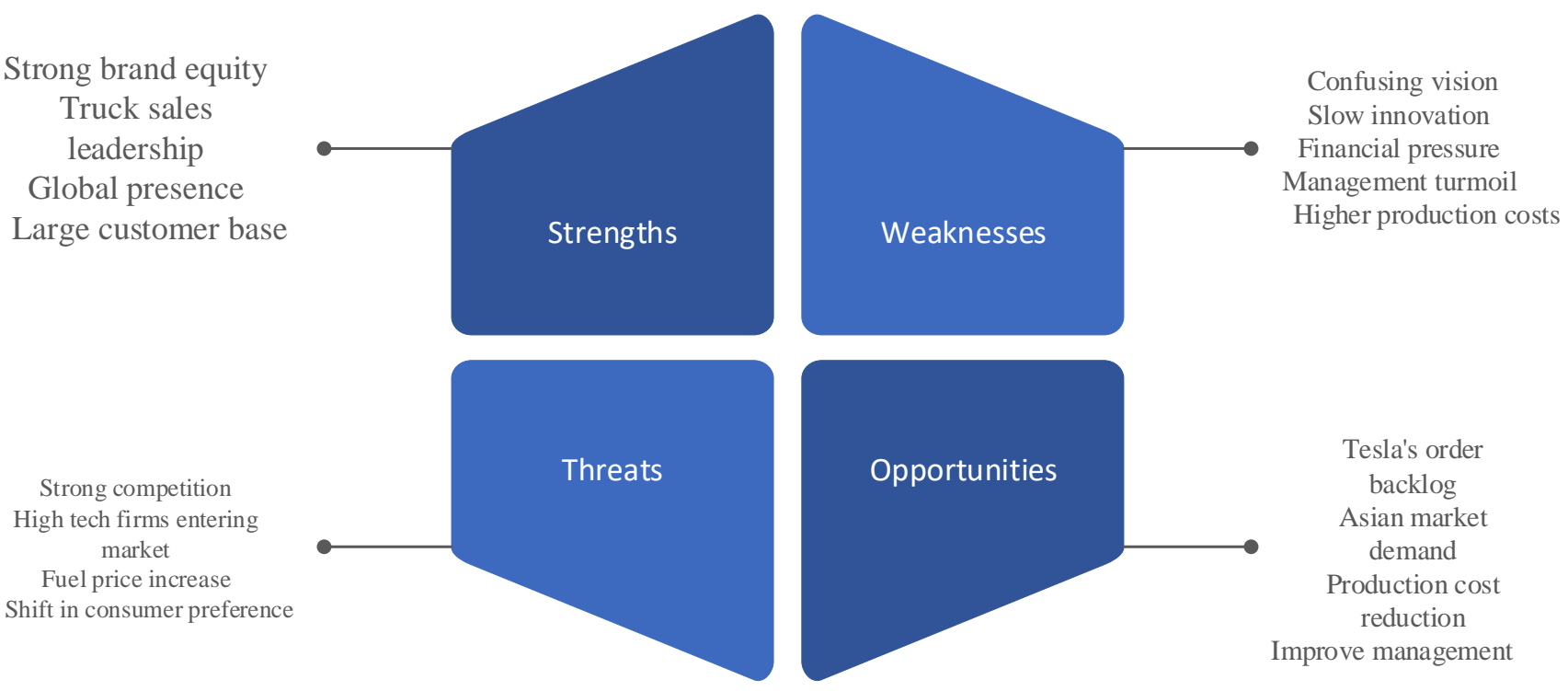

Figure 10 SWOT

\section{Strengths}

Brand Equity: As a century-old company that has the bestselling vehicle in the US for many years, the company enjoys strong brand equity and recognition. Its leadership in the truck market is one enjoyed by only a few.

Global Presence: The company has manufacturing sites and sales channels with a global presence. This translates into the ability to reach a large customer base.

Advanced Logistics: The company's relationship with Penske Logistics strengthens Ford's market dominance by introducing increased efficiencies. 
Large customer base: The combination of the above-mentioned elements has produced a large customer base that spans the globe and many generations and is one of the company's greatest strengths.

\section{Weaknesses}

Confusing vision: The new company vision leaves many gaps in terms of the direction that the company is headed. Ford has publicly indicated that it will be in the vehicle industry, yet it is unclear if it is going to be a manufacturer that sells through franchised dealers or is it going to compete against them with its ride-sharing service. After all, franchised dealers sell to the ridesharing companies. This can be the case with hourly employees and the dealer network. Are they going to compete with Toyota or Uber?

Financial pressure: The company continues to feel the burden from its financial position, especially considering its recent stock downgrade. These financial pressures can hinder innovation and growth, as the company is unable to source top resources or compete with new market entrants.

Slow innovation: Ford is behind the competition when it comes to electrified and autonomous vehicles, although, the market is relatively small today. The main problems here are a lack a fully autonomous vehicle, and it does not have the technology, nor the infrastructure to produce the large capacity batteries needed in fully electric vehicles. In fact, its competitors in China and Tesla in the U.S have these abilities. In other words, Ford is ill-positioned to compete.

Management turmoil: It is publicly known that Ford's previous CEO, Mark Fields was recently ousted for his failure to deliver adequate results. Furthermore, other top company leaders have 
also been forced to resign for misconduct. These are indicators of a larger, problem, maybe the tip of the iceberg since top leadership greatly influences company culture.

Higher production costs: Ford's low profitability suggests that it is necessary to reduce production costs in order to become profitable. Yet, the company maintains strong ties with unions and suppliers which may not be willing (or able) to reduce costs to meet the company's needs

\section{Threats}

Strong competition: Globalization has introduced many competitors in the auto industry and Ford has seen its effects. In 2016, the leading manufacturer in terms of global revenue was Toyota, and Ford was in the fifth position, slightly ahead of Honda, a company with a limited line vehicle selection.

High tech firms entering the market: The advent of companies like Google, Apple and others will increase the market pressures as these companies are well versed in the areas of innovative technologies and data analytics, which are key elements for efficient production and market knowledge. In addition, these companies bring their brand equity and global customer follow up, giving Ford a difficult environment to compete.

Market pressures: The market pressures are many, but chief amongst them is the element of a potential fuel increase that will create a seismic shift in consumer preference from trucks to more efficient passenger cars, which is the segment that Ford is abandoning. On the other hand, as new technologies become embedded in the automobile, consumers are going to expect their vehicles with the technological changes that Ford is behind. For instance, semi-autonomous driving is 
already common in all Tesla vehicles, and all luxury European brands, yet Ford is looking to introduce its autonomous vehicle after the year 2020 .

\section{Opportunities}

Tesla's back orders: The company is sitting on approximately 500,000 vehicle orders that can't deliver. This represents a golden opportunity to Ford if it is able to quickly introduce a competing product.

Asian market demand: Most of the world's population growth will come from Asia and India, and Ford is well poised to take advantage of this shift.

Production cost reduction: Ford could increase efficiencies, by increasing partnerships, like the one with Penske, to further reduce its production costs. Another example is the recently announced production of a new automatic transmission in conjunction with GM, one of its main competitors. A suggestion is to explore opportunities in the areas of electric engine and battery technologies with Tesla, areas where Ford is weak.

\section{iii. Identify and evaluate the company's current strategy}

\section{Strategic Position \& Generic Corporate and Business Strategy}

Ford is credited with inventing the concept of mass production. The original goal was to reduce costs in order to make vehicles affordable to most. These elements embody a cost leadership strategy. This approach is very similar to Ford's approach today, which relies on aggressive pricing structures to compete. After all, the competing automaker vehicles are very similar to Ford's product line. Unfortunately, Ford's earnings difficulties suggest that it has not been able to adequately reign its costs. 
Moreover, Ford has made strides to differentiate its products from the competition, by introducing new technology, yet, it has failed to introduce enough features and contrast to have a suitable differentiation strategy.

Now, the company has announced its intentions to focus on the production of trucks and sport utility vehicles, which suggests an attempt to go from a broad market approach to a narrow focus on this extremely price sensitive segment (Wheelen, Hunger, Hoffman, \& Bamford, 2015, 169). A narrow focus is a practical strategy, but not when the company is concentrating the bulk of its resources on a market segment.

Moreover, Ford has relied on its brand equity to develop a larger dealer network that blankets most markets in the U.S. This is very similar to what 7-11 and CVS pharmacies do. That is, to have a store in every corner. Likewise, it is not necessary to go far without finding a Ford dealer. It is noteworthy that Ford's brand equity has been the key driver behind the franchised dealer network because franchised dealers are financed by private individuals with a personal stake in the brand's success.

It is, however, noteworthy that Ford invested in the Chariot ride sharing venture in the San Francisco Bay Are in an attempt to enter the ride-sharing market. But, the strategy is not clear. Chariot uses vans, which suggests a carpool venture, but the reason for the ride-sharing companies' success is their nimbleness and flexibility, which a carpool company lacks.

On the other hand, Ford's success in China can be traced to a differentiation strategy, primarily because consumer preference in the region favors U.S. products.

Briefly, it appears that Ford intends to play in several industries without a clear strategy. 


\section{Review of Mission and Objectives}

The company's recent vision, used in lieu of a mission statement, is very broad. First, as previously stated it can create uncertainty with the company's stakeholders, because it is unclear if Ford is going to produce automobiles, or become a competitor to UBER, LYFT or some of the other ride-sharing platforms.

Furthermore, this broad vision has the potential to create conflicts between strategy and vision (Wheelen et al., 2015, p.168). The strategy to become a vehicle manufacturer is indeed different than the strategy to become a ride-sharing company. Technically, a manufacturer can become a provider of mobility services, like UBER or even a national Taxi company, but it will require substantial resources that Ford lacks. This idea has been mentioned as a potential use of fully autonomous vehicles, but Ford is behind its competition in autonomous vehicles technology and infrastructure. Also, what are the company objectives? This is unclear.

Overall, the vision of Ford is ambiguous, and it leaves many unanswered questions. Furthermore, this medley of goals and objectives can be the root of the company's earnings failure. A better approach is to have a clear vision centered around the company's capabilities and industry.

\section{TOWS}

\section{- Strengths and Opportunities (SO)}

○ The main opportunities are a partnership (or JV) with a strong electric vehicle manufacturer like Tesla.

○ Further market expansion in China.

- Increase development and production of sports utility vehicles 
- Strengths and Threats (ST)

- Develop more efficient engines

New product development

- Weaknesses and Opportunities (WO)

- Consolidate supplier base

- Restructure production to increase efficiencies

- Weaknesses and Threats (WT) - How can you minimize your weaknesses and avoid threats?

- Temporary retrenchment (passenger cars)

\section{Recommended Generic Strategy for Future Growth}

A global company like Ford, with multiple markets, should rely on a variety of approaches, yet all grounded-on cost leadership, this is, assuming that Ford introduces a clear vision for the future. Domestically, an adequate focus is to continue the trend of a cost leadership strategy, while introducing few products under a differentiation strategy in limited products, like what the company has done its Ford GT, and other high - performance vehicles. However, in order for this to work, Ford needs to further increase its efficiencies. Furthermore, the use of partnerships, like the one with Penske Logistics or Domino's Pizza can reduce the RD costs by serving as a testing ground for new technologies, while also measuring market support. On the other hand, a rapid development of electrified/hybrid models will provide the company with a jump-start on Tesla's order backlog. 
As for its overseas market, Ford should maintain a short-term differentiation strategy in the Asian markets, where consumer preference for the brand is high while seeking an increase in the company's efficiency in order to pivot into a cost leadership position.

\section{Risks and advantages of the proposed strategy}

The proposed strategy is to assume a cost leadership position in the US and abroad. Unfortunately, Ford has not been able to keep up with the competition, whether that is due to cultural or other reasons. It appears that Ford's structure is too ambitious for the market, which explains the decision to reduce the workforce. On the other hand, technology will continue to drive down costs, which means that the company's RD efforts need to increase.

\section{Role of globalization.}

Globalization will bring many challenges for Ford, including increased competition from non-traditional actors. Yet. It will also open the door to new markets and resources.

\section{A.3. Country Report \& Diamond Analysis}

Leading strategist and bestselling author Michael E. Porter (1990) said, “A nation’s competitiveness depends on the capacity of its industry to innovate and upgrade."

Recent global macroeconomic changes show that China certainly has the innovative ability above mentioned by Porter. These changes continue to attract newcomers and locals alike to serve the increasing demands of a rapidly expanding market. In the case of Ford, its undertaking into China can be compared to the original pioneers that sought riches by heading west during the early days of the United States. China, a land rich in resources, and one of the 
world's most populated nations is a land of opportunity for many, but, challenges abound, making this journey not suitable for the unprepared organization.

\section{Firm Strategy, Structure, and Rivalry}

The Chinese market continues its rapid expansion. At the same time, the government considers the automotive industry one of its economic pillars, opening the door for a fierce rivalry between the many domestic manufacturers. It is suggested that Ford follows a cost strategy to gain market share, yet today, China is home to over forty different domestic brands, plus the foreign competitors, making this market a challenge for Ford(China Carforum, 2011). Michael Porter (1990) said that "Companies gain advantage against the world's best competitors because of pressure and challenge." Yet, innovation ushers competitive advantage, only if competitors are slow to respond (Porter, 1990). This concentration of automobile manufacturers continues to make inroads in the domestic market by steadily improving their products, while also increasing their efficiency in order to successfully maintain their market relevance (Moss, 2017). Therefore, Ford needs to continuously increase its research and development (RD) expense or fall behind the competition. This combination of forces continues to fuel innovation, as consumer's sophistication increases, and manufacturers look for the next big thing that will differentiate their products. In other words, Ford will have to up its game in order to prevail as a low-cost leader.

Furthermore, Ford's structure is not aligned to compete in China. As a company and for many years, Ford has attempted to control everything from Detroit, under an approach that many times seemed authoritarian. This approach is ineffective when used in the Chinese highly collective cultural environment. Ford will benefit from emulating Buick, the American 
automaker that in 2016 occupied the second position in terms of overall sales in the country (Statista, 2017). This appears to be, in part, a reflection of the well-known Chinese preference for American brands, but also of the company's approach to the doing business in China.

The challenge for Ford is to continuously improvements its products and in order to satisfy consumer demand for more advanced vehicles, while also seeks efficiencies to control its increasing $\mathrm{RD}$ costs.

\section{Demand Conditions}

Michael Porter (1990) said," Ultimately, nations succeed in particular industries because their home environment is the most forward-looking, dynamic, and challenging". China, one of the world's most populated countries is reflected in these words. Its estimated population of over 1.3 Billion continues to grow, albeit, its projected growth stands at less than one percent per year (Central Intelligence Agency, 2017). the country’s data also reflects a median age of 37 years old and approximately 660 million individuals on the 25-54 years old demographic (Figure 12). For the automobile industry, this is a prime group for auto purchases, because it is of working age,

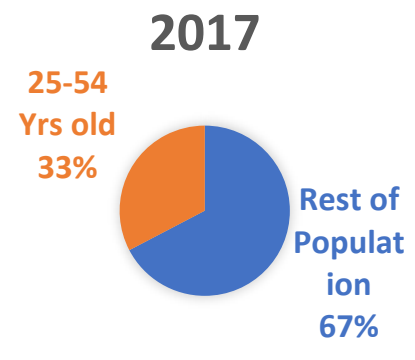
which means that they have income, and also because it is in need of mobility.

On the other hand, China is considered an
emerging economy and "In emerging markets, market demand increases sharply"

(Zhang \& Chen, 2006, p. 669). As this large mass increases its income level, its level of sophistication also increases. In this case, consumers already expect and demand more 
technology in their vehicles, which can benefit for Ford and the many manufacturers in the country, if they are able to capitalize on this new and demanding consumer (Moss, 2017).

The combination of these elements suggests future opportunities for Ford and the many automobile manufacturers in China.

\section{Related and Supporting Industries}

China can offer Ford many supporting industries. Chief amongst them, is the combination of world-class business environment, a strong manufacturing industry, and a leading OEM industry. This means that China's related and supporting industries provide a Ford with a desirable environment.

\section{Business.}

China has shown a significant increase in its business climate. Indeed, "Beijing, (is) the leader for business activity in Asia Pacific and the leader in Fortune 500 companies overall” (Dessibourg, Hales, \& Mendoza Peña, 2017, p. 7). This despite the government's attempts to intervene through its state-owned enterprise's dogma. Overall, the region is a hotbed of economic activity that can be lucrative for a multinational with significant resources.

\section{Manufacturing.}

China reputation for inexpensive production is shifting as the country continues to make significant strides to improve efficiencies and increase the sophistication of its workforce. Today, the country leads in the global production of electronics, textiles, plastics and even metal fabrication. Indeed, some of the world's leading high-tech companies, including Apple one of the world's most valuable brands, have production facilities in the country. This suggests a well- 
developed manufacturing industry, with and an industrial prowess creating a beneficial environment that certainly complements Ford's needs.

\section{OEM.}

The production of automobiles and vehicles requires many different parts, which China is can easily accommodate as one of the world's leading OEM (original equipment manufacturer) producers. Furthermore, this localized concentration of manufacturers brings a significant increase in the specialization of suppliers, which in turn have a multiplier effect on the rate of innovation, because each supplier will want to earn a larger share of its segment (Giacomin, 2017, p. 2). Albeit, it is true that in a globalized economy, sourcing of material tends to be global, China enjoys a competitive advantage in the production of OEM equipment.

Also, China is the world's leading producer of automobiles, a fact that clearly suggests that the country has a well-developed industrial environment (U.S. Department of Commerce International Trade Administration, 2017).

\section{Factor Conditions}

China presents itself as a country with ample factors of production including a large labor pool, world-class research facilities that are complemented by a growing information technology infrastructure, and significant access to capital. The relative stability of the country's currency and macroeconomic factors amplify this latter part.

\section{Labor.}

China is one of the world's most populous nations, and as such its labor pool is vast. A significant percentage of this large labor pool is skilled in industrial production. Prove of this is 
the fact that many of world's top companies have their manufacturing operations in the country. Furthermore, approximately 49 percent $(\%)$ of its population is in the 25 to 54 -year-old demographic; although, its “...per capita income is below the world average” (Central Intelligence Agency, 2017). This translates into a labor pool that is larger than the population of the United States with lower labor costs. However, its population is aging rapidly because of the one-child policy of its communist yesteryears.

\section{Research.}

China's desire to become a global innovation powerhouse is well known. The country is home to some of the leading universities and research centers in the world (U.S. News \& World Report, 2018). The importance of research is paramount, because "Firms make R\&D investments today expecting uncertain future rewards through better products or more efficient

production" (Ding, Wang, \& Wang, 2011, p. 3). Furthermore, the Chinese government continues to promote the development of research and development centers, albeit the primary focus is on the production of electrified vehicles (U.S. Department of Commerce International Trade Administration, 2017).

Additionally, the country continues to expand Information and communication technology (ICT), despite some well-known governmental censorship efforts. Actually, "China is the world's second largest ICT market" (U.S. Department of Commerce International Trade Administration, 2017). The need for ultramodern information and communication infrastructure is necessary, for the future of the automobile industry. 


\section{Natural Resources.}

China is one of the world's largest countries. Its vast territory includes many different microclimates and natural resources. For instance, "China is a world leader for hydropower because of the dozens of rivers flowing throughout the country" (Banatu-Gomez, 2007, p. 85). This capacity translates into a sustainable and potentially large electric grid, albeit its electrical infrastructure can be said that is under development. Furthermore, it is the world's top mining country, leading in the production of zinc, lead and iron ore (Basov, 2015). Although, China continues to source large quantities of commodities from Africa and Latin America. Nonetheless, the country can supply ample resources for industrial applications.

\section{Capital.}

In addition, access to capital and financing has improved, from the country's communist roots to becoming one of the world's leading financial centers today. The 2017 Global Financial Centres Index, reports that the cities of Shanghai \& Beijing are in the top 10 global financial centers (Yeandle, 2017, p. 4). An important element to consider here is that the Chinese government invests heavily in certain industries that it deems paramount for the future, and the automotive industry falls under this category (U.S. Department of Commerce International Trade Administration, 2017). All in all, these elements suggest that access to capital resources in China is favorable for the auto industry, and Ford can benefit from it.

\section{Culture}

Moreover, Ford has made significant inroads against its well-known ethnocentrism. But, to compete in China Ford needs to work harder because the company's desire to control everything from Detroit will not succeed in China. Furthermore, it is unclear at this time if 
Ford's management team is up to the task of embracing the Chinese culture. The cultural dynamics in China can be daunting for the untrained eye. For instance, in Chinese culture, it is not acceptable to say no when business discussions are taking place (Banatu-Gomez, 2007, p. 84). Furthermore, being late is considered discourteous and should be avoided at all costs (Banatu-Gomez, 2007, p. 83). Any of these or similar elements can create confusion, strife and ultimately lost efficiency.

Another key element at play is the element of Chinese preference for collectivism. This is important, because according to research, in China "Employee commitment to the organization (but not necessarily to the people in the organization) is low" (Hofstede, 2018). Collective cultures can be a powerful element for some organizations, yet Ford's culture is based on the primarily individualistic American culture.

On the other hand, many business transactions are conducted in English, which can ease interaction with potential colleagues, albeit it is best to learn some of the country's local dialects (Banatu-Gomez, 2007, p. 85) (s 85). Moreover, it is paramount to understand that many regions of China have divergent political and economic drivers and may differ from the central party or even the largest cities (Banatu-Gomez, 2007, p. 85). In other words, it can be said that China is home to a heterogeneous culture.

Briefly, China's cultural medley can be challenging, yet rewarding for the organization willing to embrace the country's social dynamics. 


\section{Caveats}

On the other hand, China does not have a well-developed infrastructure, outside of its main urban centers, a fact that is well known. Furthermore, the state continues to intervene in many industries, albeit this element is becoming less prevalent. Also, the safekeeping of intellectual property continues to be challenging, as this area continues to lack adequate legal protection. Moreover, the country also presents significant environmental challenges, caused by its rapid industrialization and lax environmental regulatory framework (Central Intelligence Agency, 2017). Briefly, these elements, while not inclusive nor disadvantageous, serve as a cautionary tale when considering China.

Moreover, Ford has chosen to rely on joint ventures to enter the market. This is an adequate approach for a company that appears to lack cultural knowledge and the workforce to embrace the Chinese market. Yet, joint ventures that fail to carefully evaluate and manage cultural divergences, especially as entrenched as the differences between the US and China, can be prone to failure. In other words, Ford needs to tread carefully when evaluating potential partners in China.

\section{Summary}

China has a large population, a growing economy and ample resources suggesting that it is a potentially lucrative market. But, it also presents itself with a medley of challenges, including a state grip on the factors of production, albeit some liberalization is on the way, lax environmental regulation and various cultural differences that can create havoc for the unprepared. Overall, the country's recent growth and growing number of multinationals on its soil suggest that the scale in favorable for its newcomers 


\section{A4: World Strategy}

Strategically, and for many years Ford's global strategy entailed concentrating most of its corporate and marketing operations in Dearborn Michigan. According to Leontiades (1985), this helps a company benefit from extensive "environmental knowledge" about its markets and industry while aiding to navigate the challenges of "national differences" (pp. 32-33). Yet, the world has evolved, and flexibility is paramount to stay competitive. Today Ford has production and research $(\mathrm{RD})$ facilities in various domestic and international destinations. Many of these units have more input in the planning process than the past. These elements open the door for a new transnational strategy that fosters growth and reduces the complexity of its product line. The bottom line is that the added autonomy of the company's global locations, the new market dynamics, and the need for strategic flexibility suggest a the pivot to a transnational strategy (Wheelen, Hunger, Hoffman, \& Bamford, 2015, p. 12).

\section{Market Development vs Product Development}

As previously said, the company owns and operates many facilities across the globe. In addition, an extensive dealer network is the main distribution channel for its products. On the other hand, Ford owns and operates manufacturing facilities capable of producing different, and at times divergent products. Based on these elements, it is adequate to consider a market penetration strategy on existing markets, while also exploring new products for expansion.

\section{Transnational Strategy}

Furthermore, the complexity of managing a global strategy under the present market conditions is extremely challenging. First, it is important to understand that the transnational strategy is being used by two of Ford's competitors. Both Toyota, and Honda, have successfully 
embraced the transnational company approach. The Economist, (2010) said that globally Toyota and Honda are among the "top 20 transnational companies by assets." They are also the only two automakers to be included in the list.

Also, a transnational strategy will help Ford increase its flexibility in areas like product development. Ford's enjoys significant brand recognition, but it is not the only brand with this trait. General Motors, Toyota, and even Tesla brands have similar recognition suggesting that their placement and promotions are similar.

\section{Growth Plan}

It can be said that the auto industry is mature with limited growth opportunities. In this case, however, the evolution of the auto industry suggests that future growth can be expected. Thus, a horizontal growth approach is suggested, which is in line with Jim Hackett (2017), Ford's new CEO who stated in a recent shareholders presentation its desire to implement new growth plans. This is in line with industry trends of introducing growth strategies to gain the favor of the company's stakeholders (Wheelen et al., 2015, p.187). The suggested approach includes a combination of market expansion, product expansion, and joint ventures.

\section{Market Penetration.}

In China, the adequate approach to increase Ford's growth appears to be the use of a market expansion approach. The company has a sizeable global dealer footprint, albeit in China it is under development. Although, in many cases, consumer preference has shifted in favor of sports utility and crossover vehicles. Ford will benefit from adopting a low-cost strategy to meet this demand (Wheelen et al., 2015, p.170). A low-cost strategy combined with Ford's name recognition can help the company increase its market share. 


\section{Product Expansion.}

On the other, the increasing demand for electrified vehicles and ride-sharing services show the direction of the industry's long-term growth. Tesla's Model 3 order backlog best exemplifies this fact (Marino-Nachison, 2018). Ford already owns and operates advanced manufacturing facilities capable of producing various products. In addition, the company has knowledgeable and skilled workers that may be able to assist with new product development. In sum, this represents an opportunity for Ford to expand its product portfolio.

\section{Joint Ventures.}

Ford could follow this two-fold approach while it seeks potential partnerships or joint ventures that help the company increase its efficiencies and growth. Ford's new CEO promotes operational redesign, the reduction of available vehicle configurations to reduce costs, and an increased focus on electrified vehicles (Hackett, 2017). However, further consolidation of the company's product lines and a return to the company's center of gravity will help Ford benefit from the experience curve an improve its efficiencies (Wheelen et al., 2015, pp.134, 185).

This combination could return Ford to a cost leadership position, allowing it to grow while it reduces its cost structure.

On the other hand, Ford should carefully continue seeking joint ventures in the areas that the company is underperforming. For instance, Ford is not a leader in the electric vehicle market. It can also benefit from improvement to its autonomous driving technology know-how. The company's new China partnership attempts to fill this gap. Under this new agreement," the new Zotye-Ford joint venture will deliver a separate range of affordable all-electric under a new brand, pending regulatory approvals"(Ford Media Center, 2017). In China, Ford can benefit 
from a partner that navigate the many layers of technical regulations and bureaucratic hurdles present. This is beneficial for both partners. One gains knowledge and the other access to more resources.

However, a potential issue is present in China, because of its policy of governmental intervention in most industries. This is problematic because Ford's global brand equity gets diluted, while it adds value to the brand of its Chinese partner. Also, China's ambiguous intellectual protection framework can lead to Ford creating its own future competitor.

\section{Caveats}

On the other hand, a strategic shift not without its challenges. For starters, Ford's semiautocratic culture where all decisions originate in Detroit is an element that needs to be managed. Similarly, establishing four global quadrants will challenge cultural integration efforts (Wheelen et al., 2015, p.139). In addition, ethical, legal, and financial issues need further evaluation.

Moreover, Ford's new CEO also implies a diversified Ford in the future. For instance, he speaks of Ford, The Mobility Company which implies more than vehicle production and includes bicycles and mass transit services. This is move should go through significant scrutiny because it moves Ford away from its core business and strengths into an unknown market. Furthermore, while the idea of diversification into related industries may be appealing, the fact is that Ford has struggled with its core business lately, thus, diversifying is not recommended at this point.

\section{Organizational Design}

The adequate design for Ford to compete on a global scale is the continued use of the machine bureaucracy approach. Since, “... machine bureaucracies fit most naturally with mass 
production, where the products, processes, and distribution systems are usually rationalized and thus easy to comprehend.”(Mintzberg, 1981, p.108). In other words, a combination of complex processes and mass production.

Ford's center of gravity continues to be centered around the mass production of vehicles, and its most adequate market strategy is a cost leadership position. The proposal, then, is that each global economic quadrant runs as a machine bureaucracy, producing vehicles for its own market. However, since standardization is needed to achieve costs reductions, the corporate office can serve as a knowledge repository where the reuse of technologies and parts across the globe is analyzed and promoted. For instance, a new electronic development devised in Asia can be adapted to the Latin America quadrant, and vice-versa. This serves as an early warning system for the company and way to increase efficiencies. Besides, it can prevent the company from being blindsided the by the rapid evolution of technology, and also mitigates the complexity of global automobile manufacturing.

On the other hand, standardization is needed for cost reduction or increased efficiencies, but fast changes in tech and customer preference can introduce significant challenges, “inadaptability” as Mintzberg (1981) calls it (p.109). Furthermore, the dynamic business environment of today requires a higher degree of flexibility that the machine approach in its pure form may not be able to accommodate (Mintzberg \& McHugh, 1985, pp.161-162). In other words, the combination of swift technological evolution, and the rapid state of manufacturing innovation leave Ford without many alternatives; it evolves, or it becomes irrelevant. 


\title{
Competition Approach
}

Hackett (2017) outlines a medley of elements as a potential approach to compete in the future. Essentially, he focuses on alliances, and joint ventures to propel the company back into profitability.

\begin{abstract}
Alliances
On the one hand, Ford's well-publicized alliance with Microsoft is laudable. Microsoft helped Ford introduce a level of technology to Ford's products that the company lacked. The companies don't have products in common preventing any potential cannibalization of sales from each other's customers. It demonstrates an adequate approach for both companies.

Another potential alliance lays in the subscription model promoted by Volvo, Cadillac BMW and even Chinese manufacturers (Markovich, 2018). It also makes sense to form alliances with international financial companies that can open the door to new markets before the model becomes a mainstream product.
\end{abstract}

\section{Franchising}

As one of the world's leading automobile manufacturers, Ford has an extensive franchised dealer network. Yet, the company has not been able to replicate the same success in China. This suggests that the region is ideal for franchise development. This is especially true now that the Chinese government has begun to make changes in its regulatory framework in response to world pressures. 


\section{Section Summary}

To conclude, Ford needs to build on its strengths. But, it needs to redirect its strategy to gain flexibility. It will also benefit from concentrating its product offerings and manufacturing vehicles efficiently and leveraging its resources to reduce costs. This means that Ford should recommit to its roots of delivering efficient vehicles. The company also needs to leverage its capabilities in the areas that the company has an advantage and enter into alliances and joint ventures in the ones that it lacks. The benefits of developing a unity of purpose and a common language are well known in the business world. On the other hand, the company's intention to diversify its core business while well intended appear to be scattered and not cohesive, as well as ill-timed and potentially distracting.

\section{A.5 Human Resources}

"All organizations exist for a purpose, and, to achieve that purpose, top management sets goals and objectives that are common to the whole organization.”(Thomson, 1998, p.2).

The accomplishment of enterprise projects and goals depends on the ability and willingness of skilled individuals. This makes the adequate management of human capital paramount, especially for a global organization like Ford. The company has responded to market pressures, under its new leadership, with a recently announced ten percent (10\%) reduction of its global workforce. A workforce reduction is not without its challenges. In fact, it is a significant undertaking that requires careful planning or risk not achieving the desired results. As the company seeks to reduce its workforce the manner and approach that this reduction is handled will determine the long-term success and viability of Ford, which forces the company's human 
resource department to operate at its best. Under this scenario, this paper introduces some of the elements to consider for the implementation of successful downsizing strategy.

\section{Background}

In 2016, Ford Motor Company employed 201,000 workers across the globe with approximately fifty percent (50\%) of it based in the United States. Despite, its large workforce, global platform, and broad product selection, the company's fortunes are creating intense market scrutiny and an underperforming stock. On the bright side, the company has realized improved fortunes in China. Nonetheless, Mark Fields, the company's previous chief executive officer was recently replaced by Jim Hackett (Rahi Kassab, 2017). The new leadership has introduced costcutting measures in order to reduce costs by approximately three billion dollars suggesting that he is assuming the position of a "turnaround specialist" (Wheelen, Hunger, Hoffman, \& Bamford, 2015, p.278). This retrenchment strategy includes a ten percent (10\%) reduction of Ford's global workforce (Rogers, 2017). Additionally, the new leadership has opted to focus the company's production on higher margin sport utility vehicles, while curtailing the production of passenger cars, even though Tesla Motors, one of Ford's competitors has been unable to deliver its order backlog of almost 500,000 entry-level electric vehicles. On the other hand, Toyota, one of Ford's main competitors, has publicly announced that it is increasing its RD expense to capitalize on the electric vehicle demand. The combination of these elements brings added pressure for Ford to increase efficiencies and capitalize on market opportunities.

\section{HR Functions}

The success of Ford is closely tied to retaining and developing the correct workforce. A ten percent (10\%) reduction of the workforce is equal to eliminating about 20,000 employees 
from the company's payroll. This is where human resource management takes center stage. To be clear, human resources focuses on five key areas, which are "...recruitment and selection, training and development, career management, performance management, and rewards...". (Dickmann \& Müller-Camen, 2006, p.585). As Ford implement its downsizing strategy, selection, training, and development assume prominence because going forward retaining and training the correct personnel can make or break the strategy and the organization. This is compounded by the risk of losing valuable knowledge by eliminating incorrect positions (Wheelen et al., 2015, p.282). Furthermore, "Disparate [human resource] systems are a major impediment to getting a holistic view of information and often provide a distorted view of HR information."(Subroto \& Satish, 2009, p.52). Also, the medley of cultures that make up Ford's global workforce magnifies these challenges.

On the other hand, Ford's workforce reduction will create the need to repatriate and relocate some employees across the globe. The return of these employees to their home country will need to be carefully managed, as some will assume new positions, while others may face unemployment. This means that human resources will also perform the functions of career management and in some cases training and development for those shifting positions. In other cases, the responsibility of relocating, retraining and in some cases provide employment assistance, to the departing workforce will need to be included. Furthermore, the remaining leadership team will need to reevaluate its strengths and weaknesses because potentially key employees will no longer be able to support leadership initiatives. To be clear, this undertaking is substantial and requires careful planning. A partial solution can be found in the implementation of self-service solutions where employees access the needed resources without the friction that corporate bureaucracy introduces (Subroto \& Satish, 2009, p.52). 
On the other hand, Ford's new CEO was introduced as a transformational leader (Bunkley, 2017). As he attempts to transform the company into a new entity, a long and hard look into the leadership ranks and their development program will have to take place, but it is safe to assume that some changes will have to take place.

The bottom line is that a downsizing move opens the door to many challenges, although a qualified human resources department can be a mitigating force against them.

\section{Strategy}

The strategy suggested by Ford's new leadership is not without its challenges. According to Wheelen, et al., (2015), the possibility of Ford achieving the desired cost reductions is very narrow (p.282). Albeit, Subroto (2009) suggests that the organization's structure and its human capital needs to be in optimized with the cost leadership strategy recommended for the company.

In the case of Ford, the bulk of its workforce is in manufacturing, which requires highly standardized processes to achieve efficiency. Dickmann \& Müller-Camen, (2006) stated that "A first indicator of standardization is whether general HR principles, guidelines and objectives are internationally integrated.” (p.585). Yet, standardized processes alone are not the answer. Wheelen et al., (2015) suggest that the success of a low-cost strategy, such as the one suggested for Ford, can be cemented on continuous "training and development” (p.277).

On the other hand, Belasen, (2008) articulated that organizational learning is best achieved by harvesting the organization's collective knowledge (p.104). So, if harvesting the collective knowledge is an adequate approach for organizational learning, and training and 
development are necessary for a low-cost strategy, an approach that fosters employee learning and harvests the collective body of wisdom is necessary.

However, the achievement of these goals often requires transferring knowledge from one department or region to the other. Therefore, the organization needs to select the best individuals for the task, whether they are locals or foreigners. For instance, should overseas operations keep local employees that are familiar with the regional customs and language for training a local workforce; or, should the company keep an ethnocentric approach and only retain U.S. nationals that are experts in the subject albeit lacking the local knowledge? Bestselling author Walter Lippmann, (1921) expressed when speaking of the plights faced by trial lawyers, that in many cases "The fiction is taken for truth because the fiction is badly needed" (location 162). This simple example illustrates the danger of ignoring cultural elements when transferring knowledge.

The best choice comes from the individuals with the cultural intelligence and the knowledge to accomplish the determined objectives. This suggests then, that Ford cannot limit the candidate selection to local or foreign nationals. It needs to scan the horizon and seek the best match, which includes a consideration of cultural assumptions. As Ford reduces its workforce and retrains the remaining workers for new tasks, cultural considerations and the role played in strategy implementation becomes paramount.

\section{Choices}

The new strategy will require additional changes to the company. For many years, Ford relied on the Management By Objectives method developed by Peter Drucker, (1955) and widely used during its early years as a replacement for the old command and control management approach made popular during the war (p.102). It is an approach that is supposed to consider 
employee input into the completion of specific tasks, goals, or objectives. However, since the 1980s Ford has embraced the Total Quality Management approach to reduce the number of defects in its products. The system has served the company well, albeit it has run its course. New approaches like Six Sigma are better suited for the new efficiencies sought by the company. This means that training will become highly relevant to the employees shifting roles.

\section{Talent Retention Considerations}

As Ford reduces its workforce, it is going to be faced with the dilemma of how to select and retain the best workforce for its chosen strategy. By the same token, Ford needs to be careful not to tarnish its brand equity during this reduction because it can hinder the attraction of new talent in the future (Cappelli, 2015). People like to work for organizations that are on top of their industries and downsizing if improperly managed, can create incorrect assumptions.

\section{Retention}

An adequate scenario calls for the company to identify redundant tasks, tasks that could automated, and tasks that when outsourced create cost savings for the company. On the other hand, Ford should avoid selecting employees that will be terminated without a structured and well-defined selection process. This requires a unified and coherent communication plan that addresses the needs and cultural expectations of each region. Furthermore, elements like uncertainty avoidance, or the ways that individuals deal with the unknown needs special attention (Hofstede, n.d.). It should also include communicating the metrics used to the stakeholders involved because poor communications create the unnecessary “... risk of damaging the company's brand in the marketplace as well as injuring the company's relationship with remaining employees, which in fact may jeopardise (sic) the long-term health of the 
company."(Schreier-joffe \& Dias-abey, 2009, p.427). Once Ford determines the ideal mix of employees to be retained, it needs to develop, establish, and monitor the growth, training, and retention of these individuals. Furthermore, a review of the company's management practices and their performance is necessary. Failure to do so exposes the company to resource squandering and strengthen the competition because if not done properly, it is the most likely destination of human resources that leave the company.

Once the selection is completed, it is important to consider the potential liabilities of the company. Some of the liabilities could include long-term health care, settlement payments and other forms of compensation. In a global company like Ford, the scope of these liabilities will vary from country to country, and they must not be ignored.

\section{Diversity}

Furthermore, Ford needs to hire and retain highly skilled employees. Today's advanced production methods require employees with technological know-how to operate complex equipment. More importantly, problem-solving skills, analytical thinking, team building and the ability to communicate well their findings are paramount for the new employee cadre. The first step in this process is promoting a culture of diversity because globalization has increased the availability of knowledgeable and skilled workers to a global marketplace. This makes diversity a productive business practice because it opens the door for the best talent, irrelevant of national origin, gender, or similar considerations. Along the same lines, Ford Motor Company cannot limit its reliance to in-house staff for growth because it can hinder its strategic plans (Wheelen et al., 2015, p.246). An adequate consideration when seeking talent is to follow Porter's diamond approach to identify regions where factor conditions include human resources with the desired 
skill set for the planned strategy. These elements suggest that Ford needs to have a compensation, hiring, training and promotion system in place that considers places diversity as a crucial factor for the future. It also means that diversity should be considered as it identifies candidates for the workforce reduction plan.

\section{Geocentric Approach}

Diversity is not just about hiring a token minority employee to fill in the blanks. Organizations often rely on additional considerations for international human resource management forms. ${ }^{1}$ One is the Ethnocentric approach where nationals of the company's home assume the upper management echelons. On the other hand, the Polycentric approach concentrates natives or locals in leadership and managerial roles on the organization. Moreover, a Geocentric approach considers each the best individual for the position without much regard for nationality.

In the case of Ford, it is suggested a geocentric approach to the hiring and retention process. The geocentric approach helps with selecting the most qualified individuals because it is supposed to ignore biases towards one or another group. Previous experience shows that the company has been reluctant to include 'outsiders' in its leadership ranks, and the results are clear.

\section{Cultural Differences \& Ethics}

A workforce reduction on a global corporation like Ford requires a way to bridge cultural differences that may hinder the adoption of new processes. For instance, in China, any attempt to

\footnotetext{
${ }^{1}$ Combinations of these are also possible
} 
promote a policy outside the approval of the government can bring significant backlash to the company. The problem with this approach is that any idea that is in line with so-called 'western beliefs' like capitalism can fall under the government's wrath. The conundrum is then, how to influence the remaining workers to perform under the (new) expected metrics without aligning the organization with the cultural and (especially) political views of the host nation? This means that "Knowledge networking [which] focuses on the internal communication and coordination mechanisms used to support the creation and diffusion of ideas and experiences" needs to be in tune with the local government (Dickmann \& Müller-Camen, 2006, p.582). At the same time, organizations (and their human capital) need to be cognizant of the ethical boundaries set forth by the company and other international bodies to avoid becoming a government voice.

\section{Unions \& New Economy}

Unions are a crucial part of the automotive industry, especially in the United States. As the company reduces its workforce, the unions will have a prominent role in this reduction, especially when almost half of the company's workforce is present in the United States and are represented by collective bargaining union.

It is plausible that the company relies on temporary workers, or even contract workers as it aims to reduce its costs. Nonetheless, the use of union workers for this approach can be explored.

\section{Section Summary}

Downsizing can create a more efficient and agile organization. But, this requires the selection and training of the most qualified personnel. The bulk of this process falls under the human resource department, a department tasked with maintaining a workforce capable of taking the present and future challenges. In a global organization like Ford, this undertaking is 
exponentially increased by the cultural medley that comprises the company's workforce.

Moreover, this paper does not attempt to oversimplify a clearly complex process, it only aims to provide a brief overview of some important elements to consider.

\section{Opportunities}

- Large demand for Evs

- Increasing demand in China

- $\quad$ Strong demand for sports utility vehicles (SU)

\begin{tabular}{|l|}
\hline \\
Threats \\
- Increasing \\
competition \\
- Potential for fuel \\
price increase \\
- Shift in consumer \\
preference \\
\hline
\end{tabular}

Figure 11: TOWS

\section{Strengths}

- Well-known brand

- Large dealer network (US-EU)

- Automated production facilities

\section{SO}

- Partnership with EV producer

- Market expansion

- Increase SU product line

\section{$\underline{\text { ST }}$}

- Develop more efficient engines

- Invest in Product Development

$\bullet$

\section{Weaknesses}

- Higher production costs

- Limited product selection (now)

\section{WO}

- Consolidate supplier base

- Restructure for efficiency

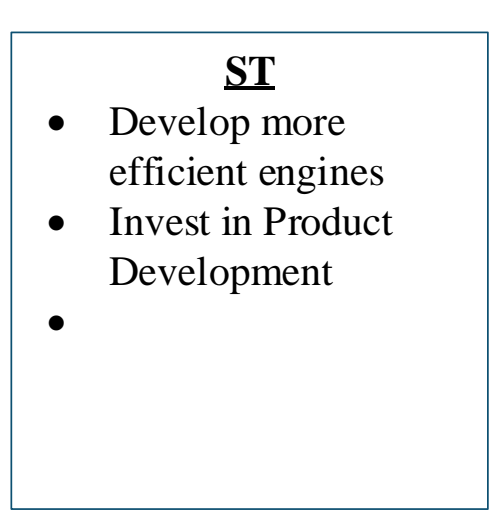

\section{WT}

- Temporary

Retrenchment (Passenger Cars) 


\section{Conclusion}

Ford pioneered the industrial revolution in the US, yet, it seems to struggle to adjust to the new global playground. As the competition increases, so will financial and market pressures. Therefore, it is paramount that Ford modifies its vision for the future and introduce necessary changes like divesting its floundering Chariot venture. 


\section{References}

Andriotis, A. (2017). Ford to Look Beyond Credit Scores to Boost Sales. Retrieved February 26, 2018, from http://www.wsj.com/podcasts/ford-to-look-beyond-credit-scores-to-boostsales/84E9BB1A-BCDC-4CFF-BAF8-C59BBBB738BE.html

Ausick, P. (2017, December 27). Ford Global Annual Sales Slip 1\% (NYSE: F). 24/7 Wall St. Retrieved from https://247wallst.com/autos/2017/12/27/ford-global-annual-sales-slip-1/

Belasen, A. T. (2008). The Theory and Practice of Corporate Communication: A Competing Values Perspective (Google Boo). Thousand Oaks, Ca: SAGE Publications. Retrieved from https://books.google.com/books?hl=en\&lr=\&id=dIP_UmIqazwC\&oi=fnd\&pg=PR13\&dq=b elasen+competing+values+framework\&ots=8PYtbAzNgb\&sig=evAYYOs4C4GzKM8h8C O3jbY04Bk\#v=onepage \&q=belasen competing values framework\&f=false

Bunkley, N. (2017, May 29). Ford gets a "proven transformational leader." Automotive News. Retrieved from http://www.autonews.com/article/20170529/OEM02/170529820/ford-getsa-proven-transformational-leader-8217

Butters, J., Welch, D., \& Naughton, K. (2018, February 6). Trump Did GM and Ford's Foes a Major Favor by Cutting U.S. Taxes. Bloomberg. Retrieved from https://www.bloomberg.com/news/articles/2018-02-06/trump-did-gm-and-ford-s-foes-amajor-favor-by-cutting-u-s-taxes

Cappelli, P. (2015, November). What It Really Takes to Attract Top Talent. Harvard Business Review. Retrieved from https://hbr.org/2015/11/what-it-really-takes-to-attract-top-talent 
China Carforum. (2011). Chinese Auto Manufacturers List - Information on Car, Truck, Bus, Motorcycle Makers in China (chery automobile, geely, gwm etc.). Retrieved April 25, 2018, from http://www.chinacarforums.com/chinese_car_manufacturers.html

DeBord, M. (2017, January 27). Ford CEO on changing business and dealer network. Business Insider. Retrieved from http://www.businessinsider.com/ford-ceo-says-business-changingdealer-network-2017-1

Dickmann, M., \& Müller-Camen, M. (2006). A typology of international human resource management strategies and processes. International Journal of Human Resource Management, 17(4), 580-601. https://doi.org/10.1080/09585190600581337

Drucker, P. (1955). The Practice of Management (Revised Ed). Burlington, MA: Elsevier. Retrieved from https://books.google.com/books?hl=en\&lr=\&id=C_EJBAAAQBAJ\&oi=fnd\&pg=PP1\&ots= xFbrihtIqN\&sig=YcX185QGVFyf9xE4Ud4mgEQwI3c\#v=onepage\&q\&f=false

Ford Media Center. (2017). Ford Intensifies China Growth Plan: More Smart Vehicles, Expanded Local Production, Leaner Business Structure |. Retrieved March 26, 2018, from https://media.ford.com/content/fordmedia/fna/us/en/news/2017/12/05/ford-intensifieschina-growth-plan--more-smart-vehicles--expande.html

Ford Motor Co. (2015). Ford Motor Company 2016 Annual Report. Dearborn. Retrieved from http://shareholder.ford.com/ /media/Files/F/Ford-IR-V2/annual-report/2016-annualreport.pdf

Ford Motor Company. (2015). Accelerating Today for a Better Tomorrow Letter from William 
Clay Ford Jr. and Mark Fields, (Sustainability Report 2015/16), 19. Retrieved from www.sustainability.ford.com

Hackett, J. (2017). Ford Motor Company. Ann Arbor, Mi. Retrieved from http://shareholder.ford.com/ /media/Files/F/Ford-IR-V2/events-and-presentations/2017/1003-2017/Slides-Ford-CEO-Strategic-Update-Oct-3-2017_f.pdf

Kendall, M. (2017, April 3). Ford overtakes Uber, Waymo and Tesla in self-driving car race, report says. The Mercury News. Retrieved from https://www.mercurynews.com/2017/04/03/fordovertakes-uber-waymo-tesla-self-driving-car-race-report-says/

Leontiades, J. C. (1985). Multinational Corporate Strategy: Planning for World Markets (Google Boo). New York: Lexington Books an Imprint of the Free Press. Retrieved from https://books.google.com/books?id=sS2hp6d9VmcC\&pg=PA31\&lpg=PA31\&dq=ford+mul tinational+strategy\&source=bl\&ots=dIi0uj1H7H\&sig=I3CdJOJC8R8mw61R4Ici1cD1MfM $\& h l=e n \& s a=X \& v e d=0 a h U K E w i n 0 M b F q 4 X a A h V H n-$ AKHeWGBTAQ6AEIbTAI\#v=onepage \&q=ford multinational strategy\&f=

Lippmann, W. (1921). Public Opinion (Kindle). Wading River, Long Island: Public Domain| Kindle.

Marino-Nachison, D. (2018, February). Tesla: Here's the Long-Term Case for the Model 3. Barron's Next, Digital. Retrieved from https://www.barrons.com/articles/tesla-heres-thelong-term-case-for-the-model-3-1518534675

Markovich, T. (2018, March). Lynk \& Co Unveils 02 SUV, Its Third Vehicle. Car and Driver Blog. Retrieved from https://blog.caranddriver.com/lynk-co-unveils-the-02-suv-its-third- 
vehicle/

Merkle, E. (2018). Ford January 2018 Sales. Detroit. Retrieved from https://www.sec.gov/Archives/edgar/data/37996/000003799618000010/january2018salesfin alfilingv.pdf

Mintzberg, H. (1981). Organization design: fashion or fit? Harvard Business Review, 103-116. https://doi.org/Article

Mintzberg, H., \& McHugh, A. (1985). Strategy Formation in an Adhocracy. Administrative Science Quarterly, 30(2), 160. https://doi.org/10.2307/2393104

NASDAQ. (2018). Stock Comparison: Compare Ford Motor Company (F) to Other Stocks. Retrieved February 25, 2018, from https://www.nasdaq.com/symbol/f/stock-comparison

Penske Logistics. (2015). Six Sigma Initiatives streamline operations. Reading, PA. Retrieved from https://www.penskelogistics.com/pdfs/01_ford_case_study_updated.pdf

Rahi Kassab, C. (2017). New Ford President and CEO Jim Hackett. Retrieved April 15, 2018, from https://corporate.ford.com/company/new-ford-president-and-ceo-jim-hackett.html

Randall, T., \& Halford, D. (2018, February). How Many Tesla Model 3 Cars Have Been Made? Bloomberg. Retrieved from https://www.bloomberg.com/graphics/2018-teslatracker/?cmpid=socialflow-twitterbusinessweek\&utm_content=businessweek\&utm_campaign=socialfloworganic\&utm_source=twitter\&utm_medium=social

Reuters Staff. (2018, February 20). Uber CEO sees commercialization of flying taxis in 5-10 years. 
Reuters. Retrieved from https://www.reuters.com/article/us-uber-strategy/uber-ceo-seescommercialization-of-flying-taxis-in-5-10-years-idUSKCN1G40J3

Rogers, C. (2017). Ford to Cut Global Workforce Roughly $10 \%$ to Boost Profit Growth. Retrieved April 13, 2018, from https://www.dowjones.com/scoops/ford-cut-global-workforce-roughly10-boost-profit-growth/

Schreier-joffe, B. S., \& Dias-abey, M. (2009). Safe exits — managing redundancy. Employment Law, 427-431. $\quad$ Retrieved from http://library.esc.edu/login?url=https://search.ebscohost.com/login.aspx?direct=true \&db=bt h\&AN=47123408\&site $=$ eds-live

Shepardson, D. (2018, March 9). Automakers and their allies call for more breaks in Trump tariff plan | Reuters. Reuters. Retrieved from https://www.reuters.com/article/us-usa-tradeautos/automakers-and-their-allies-call-for-more-breaks-in-trump-tariff-planidUSKCN1GL2WQ

Statista. (2017). • Chart: Volkswagen Dominates the Chinese Car Market | Statista. Retrieved April 25, 2018, from https://www.statista.com/chart/10297/volkswagen-dominates-the-chinesecar-market/

Subroto, K., \& Satish, S. (2009). Why HR Transformation Should be a Strategic Priority for Global Organizations. @BULLET IHRIM Journal, XIII(3), 52-57. Retrieved from http://www.ihrimpublications.com/amember/Journal_Archives/vol_133/articles/IHJour_XIII_No3_p52_57.pdf

Tempkin, A. (2017, August). "Deep" Subprime Car Loans Hit Crisis-Era Milestone. 
BloombergMarkets. Retrieved from https://www.bloomberg.com/news/articles/2017-08-15/deep-subprime-car-loans-hit-crisis-era-milestone-as-woes-mount

The Economist. (2010, July). Biggest transnational companies. The Economist. Retrieved from https://www.economist.com/node/16702193

The Economist. (2011, May). The cost of calamity. The Economist. Retrieved from http://www.economist.com/node/18387016

The Economist Editorial Unit. (2017, May). Euro-area GDP growth outpaces America's Speeding up. The Economist. Retrieved from https://www.economist.com/news/finance-andeconomics/21721557-first-quarter-figures-probably-overstate-gap-between-two

Thomson, T. M. (1998). Management by objectives. The Pfeiffer Library, 20(2), 317. Retrieved from https://home.snu.edu/ jsmith/library/body/v20.pdf

Toyota. (2012). TOYOTA MOTOR CORPORATION GLOBAL WEBSITE | 75 Years of TOYOTA | Product Lineup | Vehicles. Retrieved February 25, 2018, from http://www.toyotaglobal.com/company/history_of_toyota/75years/data/conditions/product_lineup/vehicles.ht $\mathrm{ml}$

Toyota Global Newsroom. (2018). Worldwide Operations. Retrieved February 26, 2018, from https://newsroom.toyota.co.jp/en/detail/5286101/

Trefis Team. (2017). Why Honda Is Gaining Market Share In 2017. Retrieved February 25, 2018, from https:/www.nasdaq.com/article/why-honda-is-gaining-market-share-in-2017$\operatorname{cm} 767359$ 
U.S. Department of Commerce. (2016). U.S. Census Bureau QuickFacts: UNITED STATES. $\begin{array}{lll}\text { Washington } & \text { D.C. } & \text { Retrieved }\end{array}$ https://www.census.gov/quickfacts/fact/table/US/PST045216

Waldemeir, P. (2017). Ford to cut 1 , 400 jobs as pressure grows on profits. FT, 2017-2018.

Wang, X., \& Yang, Z. (2008). Does country-of-origin matter in the relationship between brand personality and purchase intention in emerging economies? Evidence from China's auto industry. International Marketing Review, 25(4), 458-474.

Wheelen, T. L., Hunger, D. J., Hoffman, A. N., \& Bamford, C. E. (2015). Strategic Management and Business Policy (fourteenth). Upper Saddle River, NJ: Pearson. 